\title{
Notes
}

\section{Men Who Own Women: A Thirteenth Amendment Critique of Forced Prostitution}

\author{
Neal Kumar Katyal
}

"He had a six-foot bullwhip and he hit me in the head with it. . . . We got home and he beat me with that bullwhip and told me to go to sleep." These are not the words of an antebellum slave but the cries of a prostitute, describing not her slave owner but her pimp. How many women live through this type of abuse every day remains unknown.

Like slaves, prostitutes are raped, beaten, and tortured at the whim of the men who control them. It is no coincidence that at the start of the twentieth century the U.S. government referred to coerced prostitution as "white slavery."2 Nor was it a clerical error which led the United Nations to address prostitution in its Working Group on Slavery. ${ }^{3}$ Indeed, international antislavery organizations such as the International Abolitionist Federation campaign against forced prostitution. ${ }^{4}$ Similarly, it was no surprise that upon his visit to

1. Diana Gray, Turning Out: A Study of Teenage Prostitution, 1 URB. LIFE \& CULTURE 401, 416 (1973) (quoting unnamed prostitute).

2. White-Slave Traffic (Mann) Act, ch. 395,36 Stat. 825 (1910) (codified as amended at 18 U.S.C. $\S \S 2421-2424$ (1988)).

3. See, e.g., Activities for the Advancement of Women: Equality, Development and Peace, Report of Special Rapporteur Jean Fernand-Laurent, U.N. ESCOR, 1st Sess., at 24, U.N. Doc. E/1983/7 (1983) [hereinafter Fernand-Laurent]; see also Testimony Presented to the U.N., WHISPER, Spring 1992, at 2.

4. Kathleen Barry, International Politics of Female Sexual Slavery, in INTERNATIONAL FEMINISM: Networking Against Female Sexual Slavery 21, 24-25 (Kathleen Barty et al. eds., 1984). Press accounts of forced prostitution also refer to it as slavery. See, e.g., Doris Anderson, Backlash Against Feminism Erodes Gains, TORONTO STAR, Mar. 23, 1992, at A19 (referring to "[f]emale slavery through prostitution"). 
Dakar, a city once famous for exporting slaves, Pope John Paul II called for people to "oppose new, often insidious forms of slavery, like organized prostitution."

This Note argues that forced prostitution is slavery for purposes of the Thirteenth Amendment's prohibition against slavery and involuntary servitude ${ }^{6}$ therefore government officials who fail to enforce laws against pimps are acting unconstitutionally. ${ }^{7}$ Part I defines and describes forced prostitution. Part II shows that abolitionists condemned masters' exploitation of female slaves' sexuality as one of the evils of slavery and equated it with prostitution. Part III surveys Thirteenth Amendment jurisprudence and demonstrates that forced prostitution violates the Amendment. Part IV explores potential remedies against state officials for failing to protect prostitutes' constitutional rights.

While the idea that forced prostitution is slavery may not be immediately apparent to some readers, the legal system takes for granted the analogy between specific performance in personal service contracts and slavery. But should Thirteenth Amendment protection be reserved for James Taylor as he attempts to get out of a contract to sing, ${ }^{8}$ or should it be used to free people who are literally treated as chattels?

As we come closer to an understanding of what forced prostitution means for the women involved, the similarities between forced prostitution and slavery appear striking: Both pimps and antebellum slave masters have and had economic investments in women's sexual functions. Like the slaves of old, prostitutes today are forced to act against their will and sleep with their masters and other men. Like masters of old, pimps are organized, albeit loosely, and return fugitive women to each other. ${ }^{9}$ In short, forced prostitution,

5. Pope Warns of "New Forms of Slavery" on Visit to Slave Island, AGENCE FRANCE PRESSE, Feb. 22, 1992.

6. "Neither slavery nor involuntary servitude, except as a punishment for crime whereof the party shall have been duly convicted, shall exist within the United States, or any place subject to their jurisdiction." U.S. CONST. amend. XIII, \$ I.

7. Both Akhil R. Amar \& Daniel Widawsky, Child Abuse as Slavery: A Thirteenth Amendment Response to DeShaney, 105 HARV. L. REV. 1359 (1992) (discussing Thirteenth Amendment response to child abuse in DeShaney), and Joyce E. McConnell, Beyond Metaphor: Battered Women, Involuntary Servitude and the Thirteenth Amendment, 4 YALE J.L. \& FEMINISM 207 (1992) (outlining Thirteenth Amendment attack on wife batterers) suggest Thirteenth Amendment remedies for women and children who face violent (and often sexual) abuse. This Note draws on their analyses, but makes the historical claim that forced prostitution was a more central concern of abolitionists and one of the motivating factors behind the enactment of the Thirteenth Amendment.

8. In re James Taylor, 103 B.R. 511 (D.N.J. 1989) (holding that Thirteenth Amendment prohibits remedy of specific performance for breach of personal service contract).

9. "Pimps try to make you scared all the time so you won't leave them. . . . If you told on a pimp, every pimp in town would be after you-ready to kill." SUSAN HALL, GENTLEMEN OF LEISURE: A YEAR iN tHe Life of A PIMP 169 (1972); see also Charles Winick \& PaUl M. Kinsie, THe Lively COMMERCE: PROSTITUTION IN THE UNITED STATES 109-10 (1971) ("[Pimps] generally have their own code of ethics, which involves their not stealing or seducing another pimp's prostitute."). 
like slavery, implicates all of the core concerns of the Thirteenth Amendment: physical abuse, lack of free will, forced labor, and social stratification.

\section{THE PROBLEM DEFINED}

Some might argue that all prostitution is slavery and that both consensual and forced prostitution violate the Thirteenth Amendment; I make a more limited claim. Because the Thirteenth Amendment prohibits only physical or legal coercion, it reaches only forced prostitution.

Forced prostitution occurs whenever a woman is prostituted against her will, that is, physically compelled to sell herself. ${ }^{10}$ Forced prostitution is fairly common. One source claims that pimps exercise so much control over prostitution that "it is nearly impossible for a woman to ply her trade independently on the street for fear of trespassing on some pimp's territory." Pimps often "season" a new recruit with physical and verbal abuse. $^{12} \mathrm{~A}$ woman who does not make her quota for the night risks getting hit. ${ }^{13}$ Such beatings may break a woman's independence and prevent her from

10. Kathleen Barry, who has also seen the connection between forced prostitution and slavery, employs a similar definition of sexual slavery:

[I]t is carried out by pimps whose lifestyle and expensive habits are supported by one or two women whom they brutally force to sell their bodies for his profit. . . . Female sexual slavery is present in ALL situations where women or girls cannot change the immediate conditions of their existence; where regardless of how they got into those conditions they cannot get out; and where they are subject to sexual violence and exploitation. ... ... [T] he word "slavery" is not merely rhetorical.

KATHLEEN BARRY, FeMale SEXUAL SLAVERY 33-34 (1979) (emphasis omitted).

11. RUTH ROSEN, THE LOST SISTERHOOD: PROSTTTUTION IN AMERICA, 1900-1918, at 172 (1982). But see Sarah Wynter, Whisper: Women Hurt in Systems of Prostitution Engaged in Revolt, in SEX WORK 266, 268-69 (Frederique Delacoste \& Priscilla Alexander eds., 1987) (noting that between 50\% and 75\% of prostitutes have pimps). Discrepancies in the estimates of women controlled by pimps may be due in part to the fact that some women do not think of their "man" as a pimp. See D. KELLY WEISBERG, CHILDREN OF THE NIGHT: A STUDY OF ADOLESCENT PROSTITUTION 97 (1985).

Almost all prostitutes are women. Nancy Erbe, Prostitutes: Victims of Men's Exploitation and Abuse, 2 LAW \& INEQ. J. 609, 609 n.2 (1984).

12. BARRY, supra note 10 , at 78-80. Indeed, a "pimp sometimes beats a prostitute as one way of celebrating the beginning of her career with him. ... Some pimps believe that the best way to secure a woman's loyalty is to beat her into unconsciousness and then 'hump' her." WINICK \& KINSIE, supra note 9. at 119. Because a pimp is watched by other pimps to see how well he controls his women, the pimp may beat his prostitutes just to make sure that other men respect his ability to dominate his women. See Christina Milner \& Richard Milner, Black Players: The Secret World of Black Pimps 55 (1972) ("Other pimps are watchful of the degree of control that each of them demonstrates and will publicly object to any breach of this etiquette with comments such as, "That bitch better watch her ass or she gonna get beat ...."').

13. WEISBERG, supra note 11, at 109. According to one study, more than two-thirds of pimps assault the prostitutes who work for them; $18 \%$ of the prostitutes interviewed said they were beaten "constantly," while another $36 \%$ said that they were beaten "regularly." Mimi H. Silbert \& Ayala M. Pines, Occupational Hazards of Street Prostitutes, 8 CRiM. JUST. \& BeHAV. 395, 397 (1981). 
escaping. ${ }^{14}$ Meg Baldwin summed up prostitution in terms reminiscent of slavery: "To be a 'prostitute' is to be rapable, beatable, killable."15

Pimps often force women into prostitution. ${ }^{16}$ Some ply women with drugs, then take advantage of their addiction. ${ }^{17}$ Others kidnap girls and women ${ }^{18}$ or recruit them through fake employment agencies. ${ }^{19}$ Some pimps literally sell women to other pimps; according to one source, the 1977 going price for blue-eyed blondes in New York City was $\$ 1000 .^{20}$ Similarly, some pimps today will permit a woman to "buy back" her freedom by paying him money. ${ }^{21}$

The average age of beginning prostitutes is fourteen years. ${ }^{22}$ Of an estimated 1.5 million children who flee their homes each year or are homeless, approximately fifty percent engage in prostitution. " ${ }^{23}$ "P]imps do not go after young girls (12-17) because of any demand by customers for young girls. Rather, [it is] because they are naive and easy to control. . . . Once a girl is

14. "Fear of violence frequently makes escape impossible or unimaginable for many contemporary prostitutes." ROSEN, supra note 11, at 172; see also United States v. Winters, 729 F.2d 602, 605 (9th Cir. 1984) (noting experts' argument that dehumanizing conditioning process is sufficient to instill fear of retribution); HALL, supra note 9, at 163 (reporting one prostitute's claim that prostitutes fear reprisal if they leave pimps).

15. Margaret A. Baldwin, Split at the Root: Prostitution and Feminist Discourses of Law Reform, 5 YALE J.L. \& FEMINISM 47, 87 (1992). Some pimps also threaten to kill prostitutes' family members. JOHN M. MuRTagh \& Sara Harris, CAST THE FirST Stone 65 (Greenwood Press 1978) (1957).

16. Gangs have also been known to force women into prostitution. CLIFFORD L. LINEDECKER, CHILDREN IN CHAINS 130 (1981) (describing how a gang traded women for motorcycles). A govemment report concluded that one gang's treatment of its women members "borders on slavery." PRESIDENT'S COMM'N ON ORGANIZED CRIME, THE IMPACT: ORGANIZEd CRIME TODAY 67 (1986).

17. Stephen Barlay, Bondage: The Slave TrafFic IN WOMEN TOday 7 (1968) (noting that "the new armoury of the slavers includes the more sophisticated use of fashionable drugs").

18. BARRY, supra note 10 , at $73,94-96$. (1987).

19. Lan Cao, Note, Illegal Traffic in Women: A Civil RICO Proposal, 96 YALE L.J. 1297, 1299

20. BARRY, supra note 10, at 91; see also WINICK \& KINSIE, supra note 9, at 117. In one autobiographical account, a pimp tried to "return" a prostitute he had bought from another pimp in terms that underscore the commodification of women:

"I want my three bills back. That pretty bitch ain't turned three tricks since you sold her to me."

-..

The seller said, "Jack, I sold you the package as is. I ain't responsible for divine acts."

The buyer said, “. . . Give me [\$150] and take the bitch back."

The seller said, ". . . The bitch was whole when I sold her. . . . Maybe you stomped on the package."

ICEBERg SLIM, PIMP 105 (1972); see also Illinois Legislative InVESTIGatTNG CoMM'N, SEXUAL EXPLOITATION OF CHILDREN: REPORT TO ILL. GEN. ASSEMBLY OF 1980, at 243 (1980) ("[T]hese pimps will often trade girls for lump sums of money.").

21. BARRY, supra note 10 , at 98 . Slaves were sometimes allowed to buy their freedom as well. See LAURA S. HAVILAND, A WOMAN's LIFE-WORK, LABORS AND EXPERIENCES 234-36 (1889), reprinted in BLACK WOMEN IN White AMERICA: A DOCUMENTARY History 40, $40-41$ (Gerda Lerner ed., Vintage Books 1973) (1972) [hereinafter BLACK WOMEN].

22. Margaret A. Baldwin, Pornography and the Traffic in Women: Brief on Behalf of Trudee AblePeterson, et al., Amici Curiae in Support of Defendant and Intervenor-Defendants, Village Books v. City of Bellingham, 1 YALE J.L. \& FEMINISM 111, 123 (1989) [hereinafter Baldwin Brief].

23. Child Victims of Exploitation: Hearing Before the House Select Committee on Children, Youth, and Families, 99th Cong., 1st Sess. 16 (1985) (statement of Rep. George Miller) (citing 1983 figures from U.S. Dept. of Health and Human Services) [hereinafter Child Victims Hearing]. 
acquired, she is that pimp's "property.",24 Runaways face unsavory choices, for "pimps, thieves, muggers, drug dealers, rapists, pornographers, and tricks [are] ready to pounce" on runaways and these children are "subjected to the terrifying ritual of 'choose or lose,' in which the pimps give [them] a choice of picking one of them as [their] master, or being beaten or killed if [they] refuse." ${ }^{25}$ Indeed, some parents sell their children to pimps or force their own children into prostitution. ${ }^{26}$

In 1982, the most recent year for which statistics are available, there were between 200,000 and 900,000 child prostitutes in the United States. One source has calculated that, if one accepts the lower figure, child prostitution is at least a $\$ 2$ billion annual business. ${ }^{27}$ In $1988, \$ 40$ million per day was spent on prostitution. ${ }^{28}$ It has been estimated that at least 1.5 million visits to prostitutes occur in the United States every week. ${ }^{29}$

State laws do criminalize forced prostitution, but their enforcement is sadly ineffectual at best. ${ }^{30}$ As one observer put it: "[T]he violence, abuse, and degradation of [prostitutes]-remain invisible to and low priorities for the nation's law enforcement agencies." ${ }^{31}$ Instead of trying to combat the root of the problem-pimps-law enforcement's typical response is to arrest its victims-prostitutes. This practice only strengthens a woman's dependence on

24. IllinOIS LEGISLATIVE INVESTIGATING COMM'N, supra note 20 , at 243 (testimony of unnamed prostitute). Abused children are easier for pimps to condition to further abuse. See $i d$. at 261; WEISBERG, supra note 11, at 109.

25. Exploitation of Runaways: Hearing Before the Subcomm. on Children, Family, Drugs, and Alcoholism of the Senate Comm. on Labor and Human Resources, 99th Cong., 1st Sess. 28 (1985) (statement of Cheryl McCall, Life Magazine Reporter). See generally Child Pornography and Pedophilia: Hearings Before the Permanent Subcomm. on Investigations of the Senate Comm. on Governmental Affairs, 99 th Cong., Ist Sess. (1985); ROSEN, supra note 11, at 173-74.

26. Daniel S. Campagna \& Donald L. Poffenberger, The Sexual Trafficking in Children 101 (1988). One Colorado couple sold their child to a Texas businessman for $\$ 3000$. LINEDECKER, supra note 16, at 33. Another mother forced her child into prostitution by threatening to beat her. People v. DeLoach, 207 Cal. App. 3d 323 (1989). One pimp made friends with workers in a credit union, who notified him of parents who needed cash quickly. CAMPAGNA \& POFFENBERGER, supra, at 106. For other accounts of sales of children, see GITTA SERENY, THE INVISIBLE CHILDREN 6-8 (1985) (describing sale of children to pimps in New York as "auctions"); Child Victims Hearing, supra note 23, at 8 (statement of Rep. David S. Monson) (reporting $\$ 20,000-\$ 30,000$ sales prices for children).

27. Child Victims Hearing, supra note 23, at 90 (statement of Michael Jupp, Exec. Dir., Defense for Children International-USA). It is estimated that between 500,000 and one million juveniles are prostitutes or engaged in pornography. Priscilla Alexander, Prostitution: A Difficult Issue for Feminists, in SEX WORK, supra note 11 , at $184,204$.

28. Carole Pateman, The Sexual Contract 189-90 (1988).

29. M. Anne Jennings, The Victim as Criminal: A Consideration of California's Prostitution Law, 64 CAL. L. REV. 1235, 1251 (1976) (noting that this is a conservative estimate).

30. Catharine A. MacKinnon, Feminism Unmodified 5 (1987) ("These abuses are as allowed de facto as they are prohibited de jure."); see LINEDECKER, supra note 16, at 286 ("Pimps are seldom arrested.").

31. Cao, supra note 19, at 1297; see also ROSEN, supra note 11 , at 176 ("Prostitution laws . . . are selectively enforced against women and not men. Among prostitutes, laws are selectively enforced against the most powerless individuals, the streetwalkers, drawn disproportionately from the ranks of racial minorities, the poor, the very young, and the drug-addicted.") (footnote omitted). The attitudes of police mirror those of society at large: "Norms and sanctions are rarely applied against female sexual slavery. . . . [A pimp] is out of control with permission." BARRY, supra note 10, at 215-16. 
her pimp, forcing her more into his debt. ${ }^{32}$ Police rarely listen to prostitutes who claim they have been abused by their pimps, ${ }^{33}$ and at times police assault or sexually coerce prostitutes. ${ }^{34}$ As one prostitute put it, "I can't tell you the countless times I've heard police say that a prostitute can't be raped. . . A After a while you stop telling the police. ${ }^{335}$ Even if prostitutes were immune from arrest, most are too scared to turn in their pimps, ${ }^{36}$ for federal laws are rarely enforced. ${ }^{37}$ The solution is not more law, but enforcement of current laws.

The Thirteenth Amendment offers hope: forced prostitution was one of the central concerns of abolitionists, a concern eventually embodied in the Thirteenth Amendment. Forced prostitution is not merely analogous to slavery, it is slavery. Moreover, because the Amendment prohibits state inaction, states that do not take steps to eliminate slavery will run afoul of it. Therefore, states will be acting unconstitutionally unless they act to eliminate forced prostitution.

\section{OUR ABOLITIONIST ROOTS}

The economics of slavery reached beyond the fields to encompass the reproductive labor of women. Yet until recently, the female slave has escaped scholarly attention. ${ }^{38}$ As one scholar put it, "[t]he sexual dynamics of slavery

32. Pimps who bail women out of jail may require them to pay back the bail with a tremendous fine. See Cao, supra note 19, at 1306 \& n.47 ("Once the pimp has paid the bail or fines, the woman is released into his custody. The pimp may then force her into more acts of prostitution to satisfy her debt to him.").

33. Jennifer James, The Prostitute as Victim, in THE CRIMINAL JUSTICE SYSTEM AND WOMEN 291, 304-05 (Barbara R. Price \& Natalie J. Sokoloff eds., 1982); see also Belinda Cooper, Prostitution: A Feminist Analysis, 11 WOMEN's RTS. L. REP. 99, 105 n.34 (1989); JoAnn L. Miller, Prostitution in Contemporary American Society, in SEXUAL CoERCION 45, 50 (Elizabeth Grauerholz \& Mary A. Koralewski eds., 1991).

34. In one study, $41 \%$ of prostitutes surveyed reported being assaulted by police officers. Erbe, supra note 11, at 618; see also ARLENE CARMEN \& HoWARD MOODY, WORKING WOMEN 189 (1985) (noting that prostitute "may be raped, beaten, and molested by other people-even the police-and have little recourse because of her 'label"'). See also Gloria Lockett, What Happens When You Are Arrested, in SEX WORK, supra note 11 , at $39,39-40$ (describing incidents where police physically and sexually mistreated prostitutes); Karen, Police as Pimps, in SEX WORK, supra note 11, at 58, 58 (describing vice officer protecting prostitute in exchange for sex and part of her earnings).

35. Carole, Interview with Debra, in SEX WoRK, supra note 11, at 91, 95; see also Karen, The Right to Protection from Rape, in SEX WORK, supra note 11, at 145, 145-46; Carole, Interview with Barbara, in SEX WORK, supra note 11, at 166, 169 ("The police just said, 'That's the price you pay, it comes with the trade... so why bitch and scream, you're a prostitute."') (alteration in original). Prosecutors and judges also refuse to listen to prostitutes; in one case, a judge dismissed a rape charge with the statement, " $a$ whore is a whore is a whore." Alexander, supra note 27, at 184, 185 (quoting judge in Pasadena, California). In another, a district attorney dropped 29 of 32 charges against a man accused of raping six women because a majority of the victims were prostitutes. Id. at 185 .

36. "Fearing-for excellent reasons-retribution at the hands of a procurer, a victim often prefers to endure ongoing exploitation rather than face the uncertain prospects of a witness stand . . ." CAMPAGNA \& POFFENBERGER, supra note 26, at 90; see also id. at 111 .

37. One commentator views the Mann Act as ineffective because it led to only 14 convictions in 1980 , 16 in 1981, and 8 in the first nine months of 1982. WEISBERG, supra note 11, at 208.

38. Deborah G. White, AR'N'T I a Woman?: Female Slaves in the Plantation South 17-22 (1985). For recent studies concerning the sexual abuse of female slaves, see SUSAN BROWNMILLER, Against OuR Will 165-84 (Bantam Books 1976) (1975); Catherine Clinton, THE Plantation 
continue to lie just beneath the surface of southern history as a tightly coiled tangle of issues we must unravel." 39 It was not uncommon for observers at the time to define slavery as prostitution. ${ }^{40}$ Rev. Charles Olcott attacked the "customary ravishment and prostitution of colored women." Douglass, following Olcott's lead, said that "'every slaveholder is the legalized keeper of a house of ill-fame." "42 Consider also white Southerner Mary Chesnut's words: "Under slavery, we live surrounded by prostitutes . . . . [T] he mulattoes one sees in every family partly resemble the white children. Any lady is ready to tell you who is the father of all the mulatto children in everybody's household but her own."43

These authors sought to capture the harms of slavery by calling female slaves prostitutes. ${ }^{44}$ Through this comparison, they summed up the black female experience, from the day of purchase to the night her master came to "visit." Writings of the time reveal three different situations in which female slaves were often sexually exploited. First, when she was being sold, potential purchasers could fondle and harass her. Second, her master could molest or rape her. Third, she could be forced to have sexual intercourse with family or friends of the master, or with other slaves.

Mistress 199-222 (1982); ANGela Y. DAVIS, WOMEN, RaCE \& Class 3-29 (Vintage Books 1983) (1981); ELIZABETH FOX-GENOVESE, WITHIN THE PLANTATION HOUSEHOLD $49-50$ (1988).

39. Clinton, supra note 38, at 199; see also ADOLPH F. NiEMOELleR, SEXUAL SLAVERY IN AMERICA 63 (1935) (references to sexual abuse of slaves are "between the lines" of abolitionist literature).

40. See, e.g., Clinton, supra note 38, at 212 (mulattoes "are generally prostitutes and kept mistresses") (quoting a visitor to Louisiana in 1836); EUGENE D. GENOVESE, ROLL, JORDAN, ROLL 460 (Vintage Books 1976) (1974) ("[A]bolitionists argued that slavery as a system turned black women into prostitutes against their will ...."); THEODORE PARKER, THE NEw CRIME AGAINST HuMANITY, A Sermon, Preached at the Music Hall, in Boston, on Sunday June 4, 1854, at 38 (B.B. Mussey \& Co., Boston 1854) (criticizing Boston's return of fugitive slave to owner who wished to sell her as "a harlot for the brothels of New Orleans"); Interview with William Thomas, in SLAVE TESTIMONY: Two CENTURIES OF LETTERS, SPEECHES, INIERVIEWS, AND AUTOBIOGRAPHIES 225, 228 (John W. Blassingame ed., 1977) [hereinafter TESTIMONY] ("Some masters in Havana make their female slaves prostitute themselves for hire."); Wendell Phillips, Philosophy of the Abolition Movement, in SPEECHES, LECTURES, AND LETTERS 98, 108 (Boston, James Redpath 1863) ("The South is one great brothel, where half a million of women are flogged to prostitution, or, worse still, are degraded to believe it honorable."); Henry C. Wright, Spiritualism as a Practical Principle, THE LIBERATOR, Aug. 24, 1860, at 136 (noting that abolitionist Abby Foster spoke of "two millions of American women who are compelled by the law and religion of the nation to live in prostitution").

41. Charles Olcott, Two Lectures on the Subject of Slavery and Abolition 112 (Massillon, Ohio 1838). Olcott's work is peppered with references to slaves as "prostitutes" and slave quarters as "brothels." See, e.g., id. at 9-10, 111-12.

42. BELL HOOKS, AIN'T I A WOMAN 33 (1981).

43. MARY B. Chesnut, A DIARY from DiXIE 21 (Ben A. Williams ed., Houghton Mifflin 1950) (1905).

44. This is not to say that all abolitionists voiced these sentiments altruistically; many compared slaves to prostitutes because they wanted to protect the "purity" of the white race. For whatever reason, the elimination of sexual vice was a core concern of the abolitionist movement. 


\section{A. Slave Markets}

Sex and reproduction were at issue every time a female slave was sold on the market. ${ }^{45}$ Advertisements for slaves ${ }^{46}$ and the nudges and winks of slave traders ${ }^{47}$ highlighted the sexual connotations of slavery. Abolitionists used the lurid detail of slave auctions ${ }^{48}$ to compare slavery to concubinage and prostitution. ${ }^{49}$ In the ordinary slave markets of every Southern state, men bought sex. Moreover, there was one Southern institution that made the practice even more blatant: the fancy-girl markets, where the most beautiful slaves were sold to rich white men.

These fancy-girl markets were the most overt connection between prostitution and slavery. "If the prospective bidders had any doubts, they would strip them, especially the nice looking quadroon girls." 50 One of the major slave-trading firms opened a boarding-house for " gentlemen who wish to stay in the house with their slaves." "Sl While the majority of the fancy-girl trading took place in New Orleans, it occurred on a lesser scale throughout the

45. One slave described the procedures at a trader yard: "A buyer would ... grab a woman and try to throw her down and feel of her to see how she's put up. If she's purty strong, he'd say, "Is she a good breeder?' ... Then the buyer'd pick out a strong, young nigger boy .... [W] [Wen he got them home he'd say to them, 'I want you two to stay together. I want young niggers." Jordon Smith, in LIFE UNDER THE "PECUliar INSTITUTION" 287, 288 (Norman R. Yetman ed., Robert E. Krieger Publisher 1976) (1970) [hereinafter YETMAN]. See also BLACK WOMEN, supra note 21, at 45 ("[B]lack women bred children to the master's profit and were sexually available to any white man who cared to use them. Mulattoes or especially beautiful black girls were sold at fancy prices as concubines.").

46. "Advertisements announcing the sale of black female slaves used the terms 'breeding slaves,' 'child-bearing woman,' 'breeding period,' 'too old to breed,' to describe individual women." HOOKS, supra note 42, at 39-40; see generally THE SUPPRESSED BOOK ABOUT SLAVERY! (Carleton Publishers, New York 1864) [hereinafter SUPPRESSED BOOK]. Newspaper articles also documented the practice: "A A slave woman is advertised to be sold in St. Louis who is so surpassingly beautiful that $\$ 5,000$ has been already offered for her, at private sale, and refused." FREDERIC BANCROFT, SLAVE-TRADING IN THE OLD SOUTH 329 (Frederick Ungar 1959) (1931) (quoting Memphis Eagle and Enquirer, June 26, 1857).

47. See, e.g., AUTOBIOGRAPHY OF A FEMALE SLAVE 175 (Negro Univs. Press 1969) (1857) (describing "lascivious blink").

48. One abolitionist described a sale:

Her "owner" (who was said to be her father) took off her hood, to show her countenance, and, when she replaced it, again took it off; and in appraising her, by word and action, appealed to the lowest and basest passions of the assembled crowd. . . . "Gentlemen,' said the Auctioneer," (taking off her hood), "did you ever see such a Face and Head, and Form as that? Look at this!" (pulling up her clothes and showing her limbs,).... "I don't want to make any reflections on the character and standing of the 'highly respectable gentlemen' before me, but you must all be aware that nothing improves a man's taste so much as the study of the works of nature ... and by buying this magnificent specimen you will have an opportunity of indulging it to the fullest extent! Come, gentlemen, how much more am I bid for this splendid Nigger . . .." SUPPRESSED BOOK, supra note 46, at 172-73 (quoting abolitionist witnessing South Carolina auction).

49. "The more Anglo-Saxon blood . . . the more gold . . . because they are sold to be concubines for white Americans. They are not sold for plantation slaves." Speech by Sarah P. Remond, Delivered at the Music Hall, Warrington, England 24 Jan. 1859, WARRINGTON TIMES, Jan. 29, 1859, reprinted in 1 THE BlACK ABOLITIONIST PAPERS 435, 438 (C. Peter Ripley ed., I985).

50. BANCROFT, supra note 46 , at 334 n.45 (quoting authority on slave-trade customs). The top hotels had rooms where buyers could "inspect" the slaves in private. Id. at 333-34 (noting that "inspections" could be "as close as anyone wished").

51. Id. at 325 (quoting Picayune, Oct. 11, 1860). 
country. ${ }^{52}$ In addition to such markets, women were sold on the street: "[T]he girls were required to stand on an open porch fronting the street so as to attract the attention of possible purchasers. One of the girls in the yard, who had been sold conditionally for the worst of purposes and was soon returned as unsatisfactory, was mercilessly flogged." ${ }^{.53}$ Both the fancy-girl markets and ordinary street sales of women centered on young women being forced to stand either near a street or hotel (depending upon the "desirability" of the woman), in order to attract men with their beauty. As Douglass proclaimed:

I hold myself ready to prove that more than a million of women, in the Southern States of this Union, are, by the laws of the land, and through no fault of their own, consigned to a life of revolting prostitution .... I am also prepared to prove that slave breeding is relied upon by Virginia as one of her chief sources of wealth. It has long been known that the best blood of old Virginia may now be found in the slave markets of New Orleans. It is also known that slave women, who are nearly white, are sold in those markets, at prices which proclaim, trumpet-tongued, the accursed purposes to which they are to be devoted. Youth and elegance, beauty and innocence, are exposed for sale upon the auction block; while villainous monsters stand around, with pockets lined with gold, gazing with lustful eyes upon their prospective victims. ...

Every slaveholder is a party, a guilty party, to this awful wickedness. $^{54}$

While a female slave's terror began in the market, it reached its height after she arrived "home." Some masters forced their slaves to breed with others to produce offspring for market. This situation raised issues of force, ownership of human bodies, and profit from traffic in flesh-issues that are at the heart of the contemporary debate over forced prostitution.

\section{B. Sexual Abuse of Slaves on the Plantation}

Rape was a fact of life for antebellum female slaves. ${ }^{55}$ The absolute

52. Id. at 328.

53. Id. at 331 .

54. Frederick Douglass Discusses Slavery, 1850, in A DOCUMENTARY HISTORY OF THE NEGRO PEOPLE IN THE UNITED STATES 309, 313 (Herbert Aptheker ed., 2d ed. 1969). Elsewhere, Douglass made several statements against the rape of female slaves. See, e.g., 2 FREDERICK DouglasS PAPERS: SERIES ONE: SPEECHES, DEBATES, AND INTERVIEWS 12, 26, 96, 396 (John W. Blassingame ed., 1982); 3

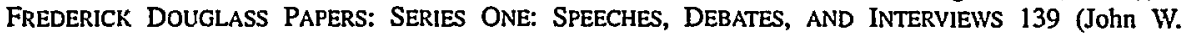
Blassingame ed., 1985). An apocryphal story about Abraham Lincoin concerns the fancy-girl markets in New Orleans. As the story goes, after witnessing prospective buyers harass a "beautiful mulatto girl," a twenty-one-year-old Lincoln muttered: "If I ever get a chance to hit that thing I'll hit it hard." BENJAMIN QUARLES, LINCOLN AND THE NEGRO 18 (1962). Such markets "aroused the special ire of the northern abolitionists." GENOVESE, supra note 40 , at 416.

55. Melton McLaurin summarized the evidence: "The literature on slavery makes it abundantly clear that white men regularly abused female slaves sexually, indeed, deemed sexual access their right. Sexual 
control possessed by the master gave him the power to exploit a slave's sexuality. Southerner Fanny Kemble exclaimed that "it is notorious, that almost every Southern planter has a family more or less numerous of illegitimate colored children." 56 Abolitionists also referred to the incestuous relationship between masters and slaves, intimating that slave owners raped their own daughters. ${ }^{57}$

A central concern of the abolitionist movement was to eliminate such abuses. ${ }^{58}$ Abolitionists attacked sexual exploitation of women in all forms, whether it occurred in the prostitution houses of the North or in the slave quarters of the South. ${ }^{59}$ Abolitionist Henry Highland Garnet claimed that slave women lived "unprotected from the lust of tyrants." "60 Sarah Remond

abuse of female slaves was a prominent theme in abolitionist propaganda . . ." MELTON A. MCLAURIN, CELIA, A SLAVE 98 (1991); see also BrownmiLler, supra note 38, at 178 ("It is true, that the female slave is peculiarly exposed ... to the seductions of an unprincipled master.") (alteration in original) (quoting 1851 Louisiana Supreme Court). Even as early as 1730, an overseer was charged with being "especially vindictive to those women slaves who repel his lust in the open field." Records of the Superior Council of Louisiana, 4 LA. HIST. Q. 521 (1921).

56. Frances A. Kemble, JouRnal of a Residence on a Georgian Plantation in 1838-1839, at 10 (John A. Scott ed., Alfred A. Knopf 1961) (1863). Slave narratives also document this practice. See, e.g., Lewis Clarke, in TeSTIMONY, supra note 40, at 151, 156; Tempe Pitts, in BullwhIP DAYS: THE SLAVES REMEMBER 297, 297 (James Mellon ed., 1988) [hereinafter BULlwhIP DAYS]; Lizzie Williams, in YETMAN, supra note 45 , at $315,317$.

57. FOX-GENOVESE, supra note 38, at 315 ("Young masters fought with young slave women with whom they had played as children and whom they might already be attempting to seduce. And masters, who embodied the ultimate authority, might have sexual relations with the women they disciplined and who indeed might be their daughters."). This was also echoed in slave narratives. For example, in one narrative, a slave woman anguishes over the fate of her daughter: "[Y]ou can never understand the slave mother's emotions as she clasps her [daughter], ... and from her own experience she sees its [sic] almost certain doom is to minister to the unbridled lust of the slave-owner . . . [I] would have been glad if we could have died together there and then." AUNT BETTY's STORY: THE NARRATIVE OF BETHANY VENEY, A SLAVE WOMAN 26 (Worcester, MA, Erastus Spaulding 1889).

58. When the New York Evangelist challenged slavery, it dared a pro-slavery newspaper to answer eight questions, two of which concerned slave rape. SIDNEY E. MORSE, PREMIUM QUESTIONS ON SLAVERY 3 (New York, Harper \& Bros. 1860); see also CHARLES BeECHER, THE DUTY OF DisOBEDIENCE TO WiCked Laws: A SeRmon ON the Fugitive Slave Law 14 (New York, J.A. Gray 1851); A Debate ON SLAVERY 47-48 (Negro Univs. Press 1969) (1846) (speech of J. Blanchard) ("See yon southern Tamar, as she goes weeping from the couch of her master, to which she has been first dragged, and then thrust away, in that after-hate which in mean minds sated lust generates towards its victims. ... . [A]dultery is no crime when perpetrated upon a slave. Why? Because the principle of slavery is the cattle principle."); EDEN B. Foster, The RIGHTS of THE PULPIT, ANd PERILS of Freedom 35 (Lowell, MA, J.J. Judkins 1854) (slavery introduces "unchaste license, and profligate vices"); OLCOTT, supra note 41, at 114 ("Slavery has caused almost all the amalgamation in the country; and abolition will put an almost entire stop to it. I believe this; because there will be nothing like a necessity; no special temptation, (as there now is, on account of the unprotected condition of female slaves,) for amalgamation . . .."); JOHN G. PALFREY, PaPers ON THE SlaVe POWer 60 (Boston, Merill Cobb \& Co. 1846); Proceedings OF THe First ANNUAL

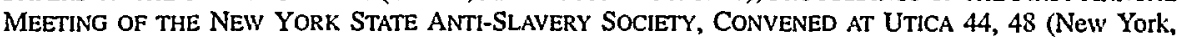
New York Anti-Slavery Society 1836) ("This is the land dedicated to amalgamation, where 500,000 mulattoes testify the affection and honorable love existing, between the master, and the female slave. This is the land where fathers sell children, and brothers and sisters, sell brothers and sisters . ...").

59. JEAN F. YELLIN, WOMEN \& SISTERS 94-95 (1989). The case of Margaret Garner became a cause célèbre. A fugitive slave, Garner upon recapture killed her own daughter because she did not want her to be a slave and possibly face the sexual terrors that Garner herself had experienced. Speech by Sarah P. Remond, supra note 49 , at $437-38,443$ n.8.

60. Introduction to Letter from Harriet A. Jacobs to Horace Greeley (June 19, 1853), in 4 THE BLACK ABOLITIONIST PAPERS 164, 164 (C. Peter Ripley ed., 1991). 
exclaimed that the 800,000 mulattoes living in the United States were all the result of rape. ${ }^{61}$ Indeed, in a famous debate on slavery, Reverend Pryne opened one of his speeches by directly attacking Southern Congressmen for raping slaves: "We send to prison . . . our violators of female chastity . . . our abductors of young girls from their homes and parents; while the South sends to Congress her ruffians who commit rape-her robbers of cradles-her violators of wives, sellers of maidens . . . whippers of women."

Echoing these claims, Harriet Martineau, an influential abolitionist, alluded to the economic motivations for rape: "Every man who resides on his plantation may have his harem, and has every inducement of custom, and of pecuniary gain, to tempt him to the common practice."63 Martineau ultimately believed that all harms of slavery arose from the master's desire to possess the sexuality of female slaves. ${ }^{64}$ Frederick Douglass likewise pleaded with his old master to prevent overseers from raping his sisters. ${ }^{65}$ This issue was not merely the concern of a few abolitionists; even the art and poetry of the time demonstrate concern with slave rape. ${ }^{66}$ In fact, by the late 1850 's many abolitionists were arguing that rape of slaves should be a crime. ${ }^{67}$

61. Speech by Sarah P. Remond, Delivered at the Red Lion Hotel, Warrington, England, 2 February 1859. WARRINGTON TIMES, Feb. 5, 1859, reprinted in 1 THE BLACK ABOLITIONIST PAPERS, sipra note 49, at 445,445 . Southern planters confirmed these high numbers: "[A] cotton planter . . . was asked what proportion of the young men of the South were clear of this practice. He answered, not more than one in ten!" Slavery As It Is, 4 THE NON-SLAVEHOLDER 112, 115 (Samuel Rhoads ed,, photo. reprint 1970) (1849); see also Kenneth M. Stamp, The Peculiar Insttution: Slavery in the ANTE-Bellum SOUTH 351 (1968).

62. Rev. W.G. Brownlow \& Rev. A. Pryne, Ought American Slavery To Be Perpetuated?: A Debate Held at Philadelphia 223 (Philadelphia, J.B. Lippincott \& Co. 1858).

63. 2 HARRIET MARTINEAU, SOCIETY IN AMERICA 320 (AMS Press, Inc. 1966) (1837) (footnote omitted).

64.

Yet these planters, who sell their own offspring to fill their purses, who have such offspring for the sake of filling their purses, dare to raise the cry of "amalgamation" against the abolitionists of the north . ... It is from the south, where this mixture is hourly encouraged, that the canting and groundless reproach has come. I met with no candid southerner who was not full of shame at the monstrous hypocrisy.

... Much that is dreadful ensues from the negro being subject to toil and the lash: but I am confident that the licentiousness of the masters is the proximate cause of society in the south and south-west being in such a state....

Id, at 328-30.

65. Frederick Douglass to His Old Master, 3 THE NON-SLAVEHOLDER 254, 256-57 (Samual Rhoads \& George W. Taylor eds., photo. reprint 1970) (1848).

66. For example, Hiram Powers' famous sculpture Greek Slave, which depicted a beautiful woman in chains, was used by many abolitionist newspapers to lament the sexual subordination of female slaves on the plantation. See YELLIN, supra note 59, at 109-12. Henry Wadsworth Longfellow's poem The Quadroon Girl also drew popular attention to the rape of slaves. His poem speaks of a planter "whose passions gave [his female slave] life,/Whose blood ran in her veins," but in the end because of poverty sells his daughter to a slave trader to "be his slave and paramour." Longfellow, The Quadroon Girl, in HARRIET B. STOWE, A KeY TO UNCLE TOM'S CABIN 150-51 (Scholarly Press 1970) (1853). Likewise, one of the very first antislavery novels described the difficult circumstances of Cassy, a slave: "She started up;-but he caught her in his arms, and dragged her towards the bed. ... [S]he looked him in the face, as well as her tears would allow her ... 'Master-Father,' she cried, 'what is it you would have of your own daughter?'" RICHARD HILDRETH, 2 THE SLAVE 9 (Boston, Massachusetts Anti-Slavery Society 1836).

67. FoX-GENOVESE, supra note 38 , at 326. 
These outcries are even more remarkable given that the Victorian spirit of the time stifled open discussion of these issues. As abolitionist Harriet Jacobs put it in her fictional but closely autobiographical account, "The secrets of slavery are concealed like those of the Inquisition. My master was, to my knowledge, the father of eleven slaves." ${ }^{68}$ Jacobs confided in Rochester abolitionist Amy Post, telling her it was much easier for a woman to "whisper" of sexual abuses than to "record them for the world to read."

Though many Southerners denied these claims, the abolitionists had a knock-down rejoinder-the ever-increasing number of mulattoes. ${ }^{70}$ Apologists argued that slaves provided a sexual outlet for white men that preserved the virtue of white women-in effect admitting that female slaves were prostitutes. ${ }^{71}$ One ardent defender of slavery conceded that Martineau's account of sexual slavery was "full of truth," stopping only to note that the "female prostitution of the South is studiously looked after, as if it were the peculiar result of slavery. She makes no corresponding inquiry into the prostitution of the North.... The fact is, that, in the Southern States, the prostitutes of the communities are usually slaves ...."72 One abolitionist argued that Southerners were as concerned about losing their free and easy access to sex as losing the labor of black men. ${ }^{73}$ Many Southerners, unable to confront the true nature of slavery, began to believe that slave women were sexual temptresses. ${ }^{74}$ 1861).

68. HARRIET A. JACOBS, INCIDENTS IN THE LIFE OF A SLAVE GIRL 55 (Published for author, Boston

69. Introduction to Letter from Harriet A. Jacobs, supra note 60, at 164. After former First Lady Julia Tyler publicly praised the benefits of slavery for the black family, Jacobs excoriated Tyler, exclaiming that a white Southern Congressman had raped Jacobs' sister. Id. at 164, 165-66 (footnote omitted). Similarly, L. Maria Child wrote about fathers selling their children, but noted that societal taboos kept her from "unveil[ing] so completely" this practice. MRS. CHILD, AN APPEAL IN FAVOR OF THAT CLASS OF AMERICANS CALLED AFrICANS 19 (New York, J.S. Taylor 1833). Other abolitionists referred to the code of silence concerning such matters. See, e.g., 2 MARTINEAU, supra note 63, at 325-26; Cruelty to Slaves, 1 The NON-Slaveholder 108, 109 (Abm. L. Pennock et al. eds., photo. reprint 1970) (1846).

70. AleXIS DE TOCQUEVILle, DEMOCRACY IN AMERICA 327 (J.P. Mayer \& Max Lerner eds., George Lawrence trans., Harper \& Row 1966) (1835); JOHN D. LONG, PICTURES OF SLAVERY IN CHURCH AND STATE 23 (Negro Univs. Press 1969) (1857) ("The best blood of the Saxon courses through their veins; the intellect of that race gleams in their eye. ... The females bring the highest prices in the South.").

71. WHITE, supra note 38 , at 39. The new Southern argument "touched a raw nerve because implicit in the argument was an admission of impropriety, namely that black women were indeed kept in a state of prostitution by white men who had little incentive to exercise self-control." Id. at 44.

72. W. Gilmore Simms, The Morals of Slavery, reprinted in THE PRO-SLAVERY ARGUMENT 175, 229 30 (Walker, Richards, \& Co., Charleston, S.C. 1853); see also HERBERT G. GUTMAN, SLAVERY AND THE NUMBERS GAME 157 (1975) (noting that one southerner "denied that free white prostitutes had a place in southern society"); Robert B. Toplin, Between Black and White: Attitudes Toward Southern Mulattoes, 1830-1861, 45 J.S. HIST. 185, 191 (1979).

73. Rev. John Long claimed that the Southern defense of slavery revolved around these lines: "It is with pain that I express the conviction that one of the reasons why wicked men in the South uphold slavery is the facility which it affords for a licentious life. . . He who defends chattel slavery must defend polygamy, for it is polygamy under another name." LoNG, supra note 70, at 263.

74. As Regina Austin put it, "Jezebel was the wanton, libidinous black woman whose easy ways excused white men's abuse of their slaves as sexual 'partners' and bearers of mulatto offspring." Regina Austin, Sapphire Bound!, 1989 WIS. L. REV. 539, 570; see also FoX-GENOVESE, supra note 38, at 292; WHITE, supra note 38 , at $28-29$. 
Slaves were not only subject to their masters' sexual whims. Masters often forced their slaves to have sex with other men, usually the master's friends:

[T] he lighter the mulatto the more desirable among the fastidious; and rare beauty is often the result of a second intermingling of the same aristocratic blood with the offspring of a former passion. From time to time, friends come to visit this bachelor hall, and in due season the master is repaid for his hospitality to them by a valuable addition to his stock of human chattels. ${ }^{75}$

Slaves were sexual commodities, whom any white man could offer to buy ${ }^{76}$ or rent ${ }^{77}$ if he felt the urge. A slave owner could also force slaves to have intercourse with his family, friends, or other slaves, and then profit from the intercourse by selling or enslaving the baby. ${ }^{78}$ Even slave owners themselves stressed the economic potential of breeding slaves. ${ }^{79}$ Since Congress had abolished slave importation in 1808 , such breeding was essential to perpetuate antebellum slavery. ${ }^{80}$

\section{The Government's View}

Congress usually refrained from discussing rape and prostitution in public. The subtext of their debates, however, reveals that many Congressmen recognized that such sexual exploitation was inextricably linked to slavery. For

75. MRS. L.J. BARKer, Influence of SLAVERY UPON THE White POPULATION 7 (New York, American Anti-Slavery Society 1855); see also SARAH GRIMKÉ, LETTERS ON THE EQUALITY OF THE SEXES AND OTHER ESSAYS 60 (Elizabeth A. Bartlett ed., 1988) (1838). Because the price of female mulatto slaves was disproportionately high, economics was often the motivating factor behind the offer of sexual services to the master's friends. OLCOTT, supra note 41 , at 112 (referring to female slaves being "reared for purposes of prostitution").

76. For example, Stowe described how a white stranger bought Lewis Hayden's mother from another owner after she rebuked the stranger's advances. Her old master sold her even though he knew why she was bought. When she refused to sleep with her new owner, he whipped her constantly, which prompted her to attempt suicide. STOWE, supra note 66 , at 155 .

77. Philo Tower, Slavery UNMASKed 322 (E. Darrow, Rochester, N.Y. 1856).

78. As one slave described, "When a girl became a woman, she was required to go to a man and become a mother. . . . Some of them had children at the age of twelve and thirteen years old. Negro men six feet tall went to some of these children." Hilliard Yellerday, in BULLWHIP DAYS, supra note 56, at 147, 147. This even led to situations where slave boys were forced to breed with their own mothers. Wesley Burrell, in BULLWHIP DAYS, supra note 56, at 297, 297. One slave maintained that female slaves on his plantation were forced to give birth to 25 or more children. John Smith, in BULLwHIP DAYS, supra note 56, at 148, 148. For other descriptions of forced breeding, see Elige Davison, in YETMAN, supra note 45, at 91, 92; Lewis Jones, in BULlWhIP DAYS, supra note 56, at 149, 149; Rose Williams, in SLAVE NARRATIVES of TeXas 20-22 (Ronnie C. Yeler \& Lawrence R. Murphy eds., 1974).

79. GUTMAN, supra note 72, at 96-97 ("Enslavement, after all, meant much more than the use of human chattel as labor. It also required ... that the slave labor force reproduce itself. Few realized this requirement better than the slaveowners .... The American Cotton Planter told of the slave 'girl' who could 'breed like a cat."'); see also WILLIAM JAY, A LETTER TO THE REV. L. SILLIMAN IVES 5 (W. Hamed, New York 1848) ("It is a practice, and an increasing practice, in parts of Virginia, TO REAR SLAVES FOR MARKET.") (quoting Thomas M. Randolph, Speech in Virginia Legislature, 1832).

80. HOOKS, supra note 42 , at 16,39 . 
example, in attempting to prevent the expansion of slavery into new territories, Senator Charles Sumner, a driving force behind abolition, lambasted Senator Andrew Butler: "Not in any common lust for power did [slavery in the new territories originate] .... It is the rape of a virgin Territory, compelling it to the hateful embrace of Slavery; and it may be clearly traced to a depraved longing for a new slave State, the hideous offspring of such a crime ...."11 Senator Butler, he continued, "has chosen a mistress to whom he has made his vows, and who, though ugly to others, is always lovely to him; though polluted in the sight of the world, is chaste in his sight-I mean the harlot, Slavery."82 Sumner's attack, which intimated that Butler had a slave mistress, led Butler's nephew, Congressman Preston Brooks, to bludgeon him with a cane until Sumner was unconscious and bleeding. ${ }^{83}$ This incident evidences the passions that the combination of sex and slavery inflamed.

Some members of Congress occasionally made more explicit references to the sexual component of slavery. Consider the words of Senator Clark: "[Slavery] has degraded the people to the infamous business of raising negroes for sale, and living upon their increase. She has practiced concubinage, destroyed the sanctity of marriage, and sundered and broken the domestic ties." ${ }^{\text {" }}$ Rep. Farnsworth used concerns about master-slave relations to counter pro-slavery sentiment. ${ }^{85}$ Other Congressmen made similar statements. ${ }^{86}$ One

81. Cong. Globe, 34th Cong., 1st Sess. 530A (1856).

82. Id. On another occasion, Sumner used similar words: "[W] hat 'just compensation' shall be voted for the renunciation of that Heaven-defying pretension, too disgusting to picture in its details, which despoils the slave of wife and child, and hands them over to lust or avarice?" CONG. GLOBE, 38th Cong., 1st Sess. 1481 (1864).

83. 4 THE WORKS OF CHARLES SUMNER 257 (n.p. 1871).

84. CONG. GLOBE, 38th Cong., 1st Sess. 1369 (1864).

85. "I am not afraid of 'miscegenation.' . . . we do not practice miscegenation; we do not belong to that school; that is a Democratic institution; that goes hand in hand with slavery. Why, sir, some of the very best blood of the Democracy of Virginia may be found . . . at Arlington today . . . ." CONG. GLOBE, 38th Cong., 1st Sess. 2979 (1864). Two years later, he repeated this charge: "Amalgamation is an outgrowth of slavery. It is where slavery has existed that you find it, not where the negro is free and has the right of selfprotection." CONG. GLOBE, 39th Cong., 1st Sess. 205 (1866). Even if some (or many) abolitionists were motivated by other concerns:

[Clourts have found that Congress intended the Thirteenth Amendment to prohibit anything with the characteristics of chattel slavery and ... sexual exploitation of women slaves was a recognized evil of the chattel slavery system, [thus] coerced sexual services . . . should be considered as falling within the scope of the involuntary servitude prohibition.

McConnell, supra note 7, at 218.

86. CoNG. GloBe, 40th Cong., 2d Sess. 465 (1868) (statement of Rep. Ward) ("[T]he only amalgamationists in this country are ... men who owned women and sold their offspring on the auction block for gold. ... . [R]econstruction [will] give these blacks citizenship, suffrage, and freedom, so that they can own themselves and protect themselves from this horrible system which slavery alone engenders."). Ward went on to lambast a Southern Congressman, claiming that "when [the Congressman] came to speak of mulattoes his yearning tenderness for the blood of the "first families" overcomes him." Id. Other Congressmen limited their comments to miscegenation, which was often nonconsensual. Rep. Rainey remarked that "occasionally it was plain to be seen that there was a strong family resemblance between [the slave and free children]." CONG. GLOBE, 42d Cong., 2d Sess. 16A (1872); CONG. GLOBE, 42d Cong., 2d Sess. 820 (1872) (statement of Sen. Wilson) ("[T]here was hardly a full-blooded black man among them. We have heard all through these forty years about these great distinctions between the races . . . and yet we have seen everywhere around us evidences that these distinctions were very often forgotten."); CoNG. 
of the most powerful statements was made by Rep. Shannon, who stated: "Slavery and barbarism are identical. ... Every form of incest is common in this, that assumes to be a paternal relation. Even polygamy is degraded by it to promiscuous prostitution." ${ }^{87}$ Finally, consider Abraham Lincoln's words in a debate against Stephen Douglas:

Could we have had our way, the chances of these black girls ever mixing their blood with that of white people, would have been diminished at least to the extent that it could not have been without their consent. But Judge Douglas is delighted to have them decided to be slaves, and not human enough to have a hearing, even if they were free; and thus left subject to the forced concubinage of their masters, and liable to become the mother of mulattoes in spite of themselves, - the very state of case that produces nine-tenths of all the mulattoes, all the mixing of blood in the nation. ${ }^{88}$

Government officials were thus well aware of the sexual subtext of slavery.

\section{The Turn of the Century Campaign Against White Slavery}

After the ratification of the Thirteenth Amendment, many abolitionists turned their attention to women forced into prostitution. An 1890 survey showed that 35 of 105 leaders of the antiprostitution movement were old enough to have been active in the antebellum antislavery movement. At least 28 of those 35 were abolitionists. ${ }^{89}$ The postbellum antiprostitution movement employed abolitionist symbols to attract former antislavery activists and used old lists of antebellum abolitionists to enlist new members. ${ }^{90}$

In describing the plight of these prostitutes, the new movement used the term "white slavery" to invoke the experience of antebellum female slaves." "[N]ew abolitionists now crusaded against white slavery, thus emphasizing

GLOBE, 39th Cong., Ist Sess. 600 (1866) (statement of Sen. Trumbull).

87. CONG. GLOBE, 38th Cong., Ist Sess. 2948 (1864). He later noted the "dusky damsels" who "pander to [masters'] laziness and lust." Id.

88. Polmitical Speeches and Debates of Abraham Lincoln and STEPHEN A. Douglas, 18541861, at 50-51 (Alonzo T. Jones ed., 1895) (commenting on the Dred Scott decision).

89. David J. PIVAR, PuRITY CRUSADE: SEXUAL MORALITY AND SOCIAL CONTROL, 1868-1900, at 68 (1973); see BLANCHE G. HERSH, THE SLAVERY OF SEX 170 (1978) ("[T] emancipation of the "white slave' was a new stage in the old abolitionist campaign. When the New York Committee for the Abolition of Regulated Vice closed its parlor meetings, members often sang the 'Battle Hymn of the Republic."'). Four years after the Thirteenth Amendment was ratified, Victor Hugo wrote to antiprostitution crusader Josephine Butler, claiming that "[t]he slavery of black women is abolished in America, but the slavery of white women continues in Europe." Josephine E. BUTLER, PERSONAL REMINISCENCES OF A GREAT CRUSADE 25 (photo. reprint 1983) (1896) (quoting letter from Victor Hugo, Mar. 20, 1870). Butler called prostitutes a "slave class" and referred to them as her "enslaved sisters." PATEMAN, supra note 28, at 196.

90. PIVAR, supra note 89 , at 67-68.

91. Supporters "used the words 'white slavery' to promote the vision of women held in bondage against their will, of mysterious druggings and abductions . . . "Marlene D. Beckman, Note, The White Slave Traffic Act, 72 GEO. L.J. 1111, 1111 (1984). 
continuity with oid abolitionism. To them any trade in bodies was slavery." These activists' efforts resulted in rescue homes for prostitutes that "suggest memories of the underground railroad"93 and culminated in passage of the White-Slave Traffic (Mann) Act in 1910, which criminalized interstate transportation of women for immoral purposes. "[T] "Te Act was so named because its central purpose was to halt ... a practice that resembled black servitude in its exploitative and barbarous nature." 95 Congressional reports on the Act powerfully connected forced prostitution and slavery: "[T]hese women are practically slaves in the true sense of the word . . . . The term 'white slave' includes only those women and girls who are literally slaves-those women who are owned and held as property and chattels-whose lives are lives of involuntary servitude . . ." In the years following the passage of the Mann Act, hundreds of pimps were arrested. ${ }^{97}$

\section{THE THIRTEENTH AMENDMENT: A CASE FOR FORCED PROSTtTUtion AS SLAVERY}

The Thirteenth Amendment is not a mere relic from bleaker days, but a command with continuing vitality. ${ }^{98}$ Indeed, the Supreme Court has

92. PIVAR, supra note 89, at 71; see also SHIRLEY J. YEE, BLACK WOMEN ABOLITIONISTS 82 (1992) (noting that abolitionist Hetty Reckless fought prostitution).

93. Egal Feldman, Prostitution, the Alien Woman and the Progressive Imagination, 1910-1915, 19 AM. Q. 192, 192 (1967).

94. White-Slave Traffic (Mann) Act, ch. 395, 36 Stat. 825 (1910) (codified as amended at 18 U.S.C. § 2421-2424 (1988)).

95. Beckman, supra note 91, at 1112. Another scholar has written that the campaign "to eradicate white slavery reminds one of the previous crusade against black servitude. In both cases its participants first pressed for international and interstate regulation of the traffic. ... [A]n abundant literature designed to expose the intricate sinister workings of the institution leave the impression of another chapter in the writings of abolitionism." Feldman, supra note 93, at 192. "White slave narratives" also exist from this

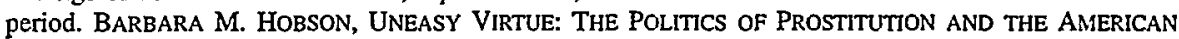
REFORM TRADITION 142 (1987). Another commentator noted:

[Chinese and Japanese women] were subject to the kind of dehumanizing objectification that Africans had experienced upon landing in the hands of southern auctioneers. ...

... Chinese white slaves became virtual chattel. ... Such women, as the Immigration

Commission recognized in their report, had "become real slaves . . . their position is practically that of permanent slavery." In other words, unless a woman, like a black slave in the nineteenth century, could buy her freedom-and legend has it that some did-she remained the property of her procurers.

ROSEN, supra note 11, at 121-22 (footnotes omitted); see also United States v. Ah Sou, 138 F. 775 (9th Cir. 1905) (upholding Chinese woman's deportation even though she was sold into slavery in China and brought into United States for prostitution).

96. H.R. Rep. No. 47, 61st Cong., 2d Sess. 10 (1909); see also S. Rep. No. 886, 61st Cong., 2d Sess. 11 (1909).

97. BARRY, supra note 10, at 29. At the same time, the Act did "not attempt to regulate the practice of voluntary prostitution." S. Rep. No. 886, 61st Cong., 2d Sess. 10 (1909).

98. See, e.g., Akhil R. Amar, Forty Acres and a Mule: A Republican Theory of Minimal Entitlements, 13 HARV. J.L. \& PUB. POL'Y 37 (1990); Amar \& Widawsky, supra note 7; Andrew Koppelman, Forced Labor: A Thirteenth Amendment Defense of Abortion, 84 Nw. U. L. REV. 480 (1990); McConnell, supra note 7. 
consistently held that the Amendment prohibits more than antebellum slavery. Soon after its ratification, it held that:

[W]hile negro slavery alone was in the mind of the Congress which proposed the thirteenth article, it forbids any other kind of slavery . . . If Mexican peonage or the Chinese coolie labor system shall develop slavery of the Mexican or Chinese race within our territory, this amendment may safely be trusted to make it void. ${ }^{99}$

This Section examines coerced prostitution through the jurisprudential lens of the Thirteenth Amendment.

Courts have used the Amendment and its legislative codifications in the criminal code, 18 U.S.C. $\$ \S 1583$ and $1584,{ }^{100}$ to outlaw a broad number of practices ranging from migrant farm labor abuses to specific performance in contracts. For example, in United States v. Booker, ${ }^{101}$ the Fourth Circuit upheld a conviction under $\S 1584$ where the defendant had coerced people into migrant labor, reasoning that the statute "must be read not only to render criminal the evil Congress sought to eradicate so long ago, but, as well, its Twentieth Century counterpart."102 This interpretation mirrors the directive we have just seen in Slaughterhouse and is true to the Supreme Court's promise that "we must accord [the Amendment] a sweep as broad as its language." 103

Some courts have complied with this charge by ruling that forced prostitution violates the Amendment. For example, Pierce v. United States ${ }^{104}$ involved a defendant who had bought clothing for women, then forced them into prostitution to pay him back. ${ }^{105}$ The Fifth Circuit upheld the defendant's conviction for involuntary servitude, repeatedly referring to the threat of violence and the exchange of cash for "dates."106

99. The Slaughter-House Cases, 83 U.S. (16 Wall.) 36, 72 (1872). The Amendment outlaws involuntary servitude of any individual, of no matter which group. Id. at 90 (Field, J. dissenting) ("Slavery of white men as well as of black men is prohibited, and not merely slavery in the strict sense of the term, but involuntary servitude in every form."). See also Bailey v. Alabama, 219 U.S. 219 (1911).

100. Section 1583 bars anyone from kidnapping or carrying "away any other person, with the intent that such other person be sold into involuntary servitude, or held as a slave." 18 U.S.C. $\$ 1583$ (1984). Section 1584 creates a cause of action against one who "knowingly and willfully holds to involuntary servitude or sells into any condition of involuntary servitude, any other person for any term, or brings within the United States any person so held." 18 U.S.C. $\$ 1584$ (1984).

101. 655 F.2d 562 (4th Cir. 1981).

102. Id. at 566 . The court stated that $\$ 1584$ "should be read as expressing the broad and sweeping intention of Congress during the Reconstruction period to stamp out the vestiges of the old regime of slavery and to prevent the reappearance of forced labor in whatever new form it might take." Id. at 565.

103. United States v. Price, 383 U.S. 787, 801 (1966).

104. 146 F.2d 84 (5th Cir. 1944).

105. Id. at 85 .

106. Id. at 85-86. The court concluded that the "evidence shows that the girls and young women employed by Pierce were required against their wills to engage in acts of immorality and to practice prostitution at [a] road house." Id. at 84. 
Similarly, in Bernal v. United States, ${ }^{107}$ the Court upheld the conviction and two-and-a-half year sentence of a defendant who was charged with holding three women in involuntary servitude. The defendant had recruited the women to work in her hotel; upon their arrival, however, the women discovered not a hotel but a brothel. The defendant had threatened one woman with deportation if she refused to prostitute herself. And in a more recent case, United States v. Harris, ${ }^{108}$ the Tenth Circuit affirmed a series of convictions for involuntary servitude arising out of a forced prostitution operation. Dicta in other cases suggest similar views. ${ }^{109}$

None of these cases, however, provides guidance about the boundaries of the Amendment, nor have they revived the close analogies between prostitution and slavery recognized by antebellum and postbellum writers. Indeed, by relying exclusively on the "involuntary servitude" provision instead of the "slavery" one, these courts neglect an argument more closely tied to the history and meaning of the Thirteenth Amendment. ${ }^{110}$ This oversight is compounded by the failure of these courts to delineate a standard for determining Thirteenth Amendment violations. What emerges from the majority of Thirteenth Amendment cases, however, are two common elements. First, the plaintiff must prove some deprivation of free will; coerced labor lies at the center of the Amendment. ${ }^{111}$ Second, recent Court rulings require a plaintiff to prove actual or threatened physical or legal coercion. ${ }^{112}$

107. 241 F. 339 (5th Cir. 1917).

108. 534 F.2d 207, 214 (10th Cir. 1976).

109. In United States v. Sanga, 967 F.2d 1332 (9th Cir. 1992), a man forced a woman to work as a domestic maid for more than two years and forced her to have sex with him. In describing these conditions, the Court described the maid as a "virtual slave." Id. at 1335. The Sixth Circuit held that a religious commune violated $\$ 1584$ by holding children against their will. Responding to the defendants' claim that parental consent shielded the commune, the court answered, "[n]either religion nor parental consent can save the Salem witch trials of children or the sale of a daughter into prostitution or the Padrone system of child labor." United States v. King, 840 F.2d 1276, 1283 (6th Cir. 1988). Also, in Ohio v. Doss, Nos. 40773, 40774, 40776, slip op. (Ohio Ct. App. May 8, 1980), a court upheld a conviction for forced prostitution based on kidnapping, reasoning that under Ohio law, "involuntary servitude" is one of the elements of "abduction."

110. This is not to suggest that the involuntary servitude provision of the Amendment has no potential. Indeed, for skeptics who still wish to force "slavery" into having only one meaning, "involuntary servitude" may offer promise of another textual hook: "The word servitude is of larger meaning than slavery ...." The Slaughter-House Cases, 83 U.S. (16 Wall) 36, 69 (1872).

111. Bailey v. Alabama, 219 U.S. 219 (1911) (voiding statute requiring compulsory labor for debts owed). Bailey noted that the statute "furnishes a convenient instrument for the coercion which the Constitution ... forbid[s]; an instrument of compulsion peculiarly effective as against the poor and the ignorant, its most likely victims." Id. at 244-45; see also Butler v. Perry, 240 U.S. 328, 332 (1916) (involuntary servitude covers "those forms of compulsory labor akin to African slavery which in practical operation would tend to produce like undesirable results"); Ex parte Virginia, 100 U.S. 339, 363 (1879) (Field, J. dissenting) (amendment covers "every other form of compulsory service for the benefit, pleasure, or caprice of others [and] was intended to render every one within the domain of the republic a freeman $\ldots$ and to enjoy equally with them the earnings of his labor").

112. In United States $v$. Kozminski, the Supreme Court refused to extend protection under $\$ 1584$ to situations where "physical or legal" coercion was not present. 487 U.S. 931,952 (1988). Indeed, a number of Thirteenth Amendment cases involve physical coercion. E.g., United States v. Harris, 701 F.2d 1095 (4th Cir.), cert. denied, 463 U.S. 1214 (1983); United States v. Booker, 655 F.2d 566 (4th Cir. 1981); United States v. Bibbs, 564 F.2d 1165 (5th Cir. 1977). 
Both the history of slavery and the jurisprudence of the Thirteenth Amendment reveal tight similarities between antebellum slavery and contemporary coerced prostitution. These similarities closely match the Amendment's standards. Antebellum slaves endured physical abuse, were forced to labor for their masters, and were treated as property. Coerced prostitutes today find themselves in exactly the same situation. The following discussion explains why forced prostitution violates the Thirteenth Amendment. ${ }^{113}$

\section{A. Compelled Labor and Sexual Commodification}

The Thirteenth Amendment reaches forced prostitution today. Pimps deprive prostitutes of their free will and their free labor in the same way that Southern slave masters deprived slaves in the 1800's. Both markets traffic in flesh, thriving on bodies and demanding that women be held against their will in sexually coercive situations. In both circumstances, women's sexual organs are forcibly commodified by slave-traders and pimps. ${ }^{114}$ Could the fancy-girl markets have remained after ratification of the Thirteenth Amendment? Is there any significant difference between those markets and the forced prostitution markets of today?

Prostitution experts believe there is not. The most forceful advocate of this view, Kathleen Barry, explicitly connects pimps and slavery: "It is currently estimated that over 90 percent of street prostitutes are controlled by pimps. ... Female sexual slavery then refers to international traffic in women and forced street prostitution taken together." 115 Similarly, a U.N.-commissioned report explicitly equated forced prostitution with slavery. ${ }^{116}$

Just as slaves were provided with minimum necessities in order to keep them working, a "pimp also supplies the basic needs of his hustlers . . . Even these needs, however, are grudgingly conceded and provided in minimum quantities on the premise that without them a juvenile [prostitute] is incapable

113. The key elements in a Thirteenth Amendment violation involve a relationship of power and physical or legal coercion. The concept of slavery under the Thirteenth Amendment, therefore, has a concrete and finite set of meanings which do not easily lend themselves to new situations.

114. A master saw his female slave as a "fragmented commodity whose feelings and choices were rarely considered. . . . Her vagina, used for his sexual pleasure, was the gateway to the womb, which was his place of capital investment-the capital investment being the sex act and the resulting child the accumulated surplus, worth money on the slave market." Barbara Omolade, Hearts of Darkness, in POWERS OF DESIRE: THE POLITICS OF SEXUALITY 350, 354 (Ann Snitow et al. eds., 1983). Yee also has argued that slavery made women "sexual commodities." YEE, supra note 92, 114, at 41 .

115. BARRY, supra note 10 , at 6.

116. Fernand-Laurent, supra note 3, at 11 ("A woman may also be sold by one procurer to another, as were slaves in the past and as is merchandise today. ... [A]ll are nevertheless subjected to the most degrading and destructive form of slavery. . . . To free oneself from a procurer, it is usually necessary to pay him a substantial "fine'...."). The Report also stresses the success of the American abolitionist movement. Id. at 36. 
of working." 117 Frequently this deprivation results in even further parallels with slavery. For example, a young prostitute "may be asked to put her baby up for adoption; in extreme situations, the infant may be taken from the mother and sold by the pimp."118 The sale of babies, though rare, is one of many examples that demonstrate that the power of pimp over prostitute often rises to that of master over slave. ${ }^{119}$ Though courts do not rely explicitly on it, unequal power is a recurring theme in Thirteenth Amendment jurisprudence. $^{120}$

The description of prostitution as outlawed by the Thirteenth Amendment is tightened by the sexual subtext of slavery. ${ }^{121}$ Fancy-girl markets in grand hotels and street auctions find their modern-day parallel in markets for call girls and street walkers. Like prostitution, forced breeding meant that women were forced to have sex against their will for the economic benefit of another. While the "fruit" of such intercourse has changed-a direct cash transfer replacing the sale of a baby-the relationship of unequal power between master and slave remains the same. ${ }^{122}$ Indeed, postbellum reformers rejected definitions of "prostitution" as solely "sexual intercourse," replacing this older definition with one that recognized prostitution as "the misuse of any power or function." "123

Young runaway girls today find themselves in the same situation as fugitive slaves did 150 years ago. They are the prey of professional enslavers,

117. Id. at 92 .

118. Id.

119. For example, just as slaves sometimes served as overseers, prostitutes today sometimes try to gain favor with their pimp by collaborating with him to recruit new women. CAMPAGNA \& POFFENBERGER, supra note 26, at 114. Just as slaveholders used lurid detail to sell their slaves, supra notes $46-48$, pimps "advertise" their prostitutes by showing pornographic pictures of them to prospective buyers, CAMIPAGNA \& POFFENBERGER, supra note 26 , at 6 .

120. Even in one of its most restrictive Thirteenth Amendment cases, the Supreme Court warned:

Our holding does not imply that evidence of other means of coercion, or of poor working conditions, or of the victim's special vulnerabilities is irrelevant ... [A] trial court could properly find that evidence of other means of coercion or of extremely poor working conditions is relevant to corroborate disputed evidence regarding the use or threatened use of physical or legal coercion ....

United States v. Kozminski, 487 U.S. 931,952 (1988).

121. One modern scholar has observed: "Free sexual access to slaves marks them off from all other persons as much as their juridical classification as property." M.I. Finlay, The Extent of Slavery, in Slavery: A Comparative Perspective 6 (Robin W. Winks ed., 1972). Similarly, McLaurin writes, "To have empowered slave women in the domestic arena, to have recognized their right to control their sexuality, would have undercut the power of the master to a degree that would have threatened the very survival of the institution." MCLAURIN, supra note 55, at 117.

122. This relationship was recognized even in 1850 , when "numerous writers were speaking out against the 'fancy-men' of prostitutes and the 'necessary evil pimps."' TIMOTHY J. GILFOYLE, CITY OF EROS 88 (1992). The use of the term "fancy-men" is striking, for it suggests that the connection between slaves and coerced prostitutes was clear at that time. A few years later, one court referred to "the sale of female slaves for prostitution" as an aspect of slavery. Osborne v. Nicholson, 18 F. Cas. 846, 849 (C.C. E.D. Ark. 1870) (No. 10,595). Likewise, the 1950's "Bronx slave market" was a fixture in the New York prostitution scene. JOHN M. MURTAGH \& SARA HARRIS, CAST THE FIRST STONE 101 (Greenwood Press 1978) (1957).

123. Pivar, supra note 89, at 33 (quoting Editorial, FAMiLY CULTURE, May 1896, at 1). 
who befriend them and claim to offer help. Just as the pimp today seeks these girls out and promises to help them escape from their parents, the slave trader of 150 years ago promised to help young black females escape from their masters. Once the slave trader had the fugitive slave in his grip, he sold her at the nearest auction. Today, child prostitution "involves torture, the purchase and sale of children, the incarceration of children so that others may make a profit, the premeditated rape and mutilation of children and, often, the death of the child .... It is probably the last vestige of wholesale slavery left on this earth." 124 According to one report, a gang offered "bounties" to encourage the capture of children who escape, and these children were subjected to beatings, burnings, and even death for their attempts to resist prostitution. ${ }^{125}$

Some might reply that prostitutes do reap the benefits of their own labor and therefore are not slaves. ${ }^{126}$ However, masters often "paid" their female slaves to have sex with them-either directly, through material gifts, or indirectly, by reducing their other duties and by not punishing them. Indeed, one important payment was that they were not sold and separated from their families. No punishment was off-limits after a slave refused to submit; ${ }^{127}$ the harsher masters of the Old South threatened to kill (the nicer ones threatened to sell) a slave woman's children. Occasionally, a woman received freedom in return for sex; more often, slaveowners gave these slaves gifts, perhaps out of guilt. ${ }^{128}$ Gifts were not just bestowed for sex, slave owners also used them

124. Child Victims Hearing, supra note 23, at 31 (statement of Michael Jupp, Exec. Director, Defense for Children International-USA); see LINEDECKER, supra note 16, at 125.

125. See, e.g., CAMPAGNA \& POFFenBerger, supra note 26, at 107-10. If a girl escapes from a motorcycle gang, a "bounty of $\$ 100$ or $\$ 200$ may be offered for her return. . . . [Those caught] face the prospect of gang rapes, beatings, intimidation, and, in extreme cases, murder. The brutal treatment of a captured nunaway is used as an example to others who might be considering fight from the club." $1 d$. at 109.

126. bell hooks has argued that antebellum slaves were quite different from prostitutes: "Since prostitutes are women and men who engage in sexual behavior for money or pay of some kind, it is a term inaccurately used when applied to enslaved black women who rarely received compensation for the use of their bodies as sexual latrines." Hooks, supra note 42 , at 33 . However, prostitutes are forced to give every cent they earn to their pimps, who then use it to "care" for them-much like slavemasters and slaves. See infra text accompanying note 133 . In fact, virtually every study of prostitute earnings concludes that most live in poverty, receiving little in return for their labor. "The average net income for a streetwalker is less than S100 a week." GAIL SheEHY, HuSTLING: PROSTITUTION IN OUR Wide-OPEN SOCIETY 5 (1973). Prostitutes rarely get five percent of what they bring home to their pimp. Id. at 6 . Moreover, as hooks recognizes, many masters paid slaves for sex. Finally, hooks makes her distinction to highlight slavery's coercion. My argument seeks to rekindle her concerns by exposing the force present in both antebellum slavery and contemporary prostitution.

127. "A Slaveholder ... recently shot a beautiful Slave girl, because she refused to comply with a proposition he had made to her. He buried her in an old log heap." SUPPRESSED BOoK, supra note 46, at 219; see also Interview with Madison Jefferson, in TESTIMONY, supra note 40, at 217, 221. Another female slave had a husband, "but that made no difference; [the master] used her whenever he saw fit. He generally carried a white oak cane, one end very heavy, and if the women did not submit, he would make nothing of knocking them right down." Interview with J.W. Lindsay, in TESTIMONY, supra note 40, at 396, 400.

128. "White male slaveowners usually tried to bribe black women as preparation for sexual overtures so as to place them in the role of prostitute. As long as the white slaveowner paid for the sexual services of his black female slave, he felt absolved of responsibility for such acts." HOOKs, supra note 42, at 25 ; 
to encourage breeding. ${ }^{129}$ In short, the context of coerced prostitution, which involves compelled sexual chores, surrounds the Thirteenth Amendment's prohibition against forced labor.

\section{B. Physical Coercion and Sexualized Violence}

Almost all Thirteenth Amendment cases involve some level of physical coercion. The magnitude of the threat, however, varies according to the circumstances. For example, a boy slapping his friend is not equivalent to a husband slapping his wife, even if the level of force is the same; likewise, the physical abuse element of the Amendment relies, in large part, on context. ${ }^{130}$ And the context of forced prostitution is strikingly similar to slavery.

The female slave was an extralegal creature, who could not use the law to protect herself: "While acknowledging that slave women were used by masters for sexual favors, state studies of slavery . . . fail to record charges against whites for rape of a female slave. Of course, the lack of such charges merely reflects that the law provided no protection to slave women against rape."131

Pimps today trace the footsteps of slavemasters by beating their prostitutes regularly. For example, "pimps control prostitutes through (1) physical abuse; (2) physical control of prostitutes' children, with threats to keep the children as hostages if prostitutes leave; (3) serious threats of physical harm, including murder; (4) keeping prostitutes in continuous states of poverty and indebtedness; and (5) ensuring that [they] have no freedom to move outside unaccompanied." 132 Prostitutes who do not bring enough money home may be beaten as were slaves who did not do enough work. ${ }^{133}$ Some prostitutes are literally branded when pimps scar and tattoo them. ${ }^{134}$ Reminiscent of the days when slaves without masters were labeled fugitives, pimps consider women without pimps "outlaws." 135 Indeed, just as slaves were beaten for

see also Lewis Clarke, supra note 56, at 157 ("They know they must submit to their masters; besides, their masters, maybe, dress 'em up, and make 'em little presents, and give 'em more privileges, while the whim lasts .....").

129. "Some slave owners devised a system of rewards to induce women to breed. But such rewards were rarely commensurate with services rendered. On some plantations a woman might be given a small pig each time a child was bom to her." HOOKS, supra note 42, at 41 . Female slaves earned food, praise from their masters, and relief from hard labor in exchange for sex. GUTMAN, supra note 72, at 97-98.

130. See supra note 120.

131. MCLAURIN, supra note 55, at 96; see also 3 JUdICIAL CASES CONCERNING AMERICAN SLAVERY AND THE NEgRo 362 (Helen T. Catterall ed., 1932) (citing Alfred v. State, 37 Miss. 296 (1859)) (slave could not testify that overseer raped her).

132. Erbe, supra note 11, at 612-13.

133. People v. Kent, 96 Cal. App. 3d 130 (1979) (prostitute beaten for not bringing enough money); HALL, supra note 9, at 86 ("The first person who comes in this house with under two hundred dollars, I'm going to throw her out the window ... you want your ass kicked, come home with no money.") (quoting a pimp); J.-G. MANCINI, Prostitutes AND Their PARASITEs 76-77 (D.G. Thomas trans., Elek Books 1963) (1962); SERENY, supra note 26, at 78.

134. CAMPAGNA \& POFFENBERger, supra note 26, at 93.

135. CARMEN \& MOODY, supra note 34, at 130; MUFTAGH \& HARRIS, supra note 122, at 129. 
trying to run away from their masters, so too are prostitutes today: "The pimp will take out a razor and say 'Bitch, you gonna leave me? I bought you all these clothes, food, gave you a place to stay." 136 Pimps sometimes kill prostitutes. This is a result of the same confluence of forces which allowed masters to maim their slaves legally and often to kill them-those who value others' lives only instrumentally do not hesitate to destroy those lives when they are no longer useful. And in stark parallel to the antebellum slave masters who tortured the children of those who refused to submit, pimps today murder and maim their women's children for any disobedience. ${ }^{137}$

Neither the societal institutions nor the people within them protected antebellum slaves or today's prostitutes. Slaves were "broken" and "domesticated" to endure sexual abuse; likewise, women and girls who have been sexually abused are targets for today's pimps. Slaves and prostitutes have been the friendless scourge of society. Moreover, police say that prostitutes who "cry" rape are just upset that they "didn't get their money." 138 When they are rape victims, both the antebellum slave and the modern prostitute are surrounded by silence.

Though prostitutes are required to prove instances of physical or legal coercion in order to prevail under the Thirteenth Amendment, they should not have to prove that escape was physically impossible. Though pimps are likely to argue that women are able to flee while on the streets looking for customers, their "blame the victims" claims are unlikely to prevail. One court rejected this argument because many antebellum slaves could have escaped while on errands for their masters. ${ }^{139}$ The Amendment, therefore, provides a viable cause of action against forced prostitution. ${ }^{140}$

136. Baldwin Brief, supra note 22, at 130 (quoting Trudee Able-Peterson).

137. One prostitute noted that when she "first started to work the street [her] 11 month old girl was murdered by [her] pimp." Id. at 134 (quoting letter from prostitute to Genesis House); see also supra text accompanying note 132 .

138. BROWNMILLER, supra note 38, at 409 (quoting police sergeant). Prostitutes who avoid arrest have been called, in words that echo slavery, "uppity niggers." CARMEN \& MOODY, supra note 34, at 139. Prostitutes "face verbal and occasionally physical abuse from police officers . . . . Pimps also feel free to discipline their women because these men know they will not be reported. The prostitutes' [sic] illegal status makes her more dependent on the pimp and more reluctant to seek the protection of the law." Jennifer James et AL., The Politics of Prostitution 42 (2d ed. 1977).

139. One court noted that "slaves often worked in the fields and went into town with little direct supervision, thereby offering them opportunities for escape. Yet it is beyond argument that the slaves were held in involuntary servitude," and that therefore "a defendant is guilty of holding a person to involuntary servitude if the defendant has placed him in such fear of physical harm that the victim is afraid to leave, regardless of the victim's opportunities for escape." United States v. Bibbs, 564 F.2d 1165, 1168 (5th Cir. 1977).

140. In her amicus brief to the court in Village Books $v$. City of Bellingham, Meg Baldwin called coerced prostitution "a condition of sex discriminatory involuntary servitude, the 'services' themselves 'running the gauntlet of sexual abuse." Baldwin Brief, supra note 22, at 146 (citations omitted). This argument does not mean that purely consensual prostitution is slavery. It is a mistake to think that women grow up wanting to be prostitutes, JOHN DAVIDSON, THE STROLL 31 (1986), but it is at least as much of a mistake to argue that a woman could never consent to become one. See Gail Pheterson, Not Repeating History, in A VINDICATION OF THE RIGHTS OF WHORES 3, 17-18 (Gail Pheterson ed., 1989); Margaret Jane Radin, Market-Inalienability, 100 HARV. L. REV. 1849, 1924 (1987). Both advocates for prostitutes and 


\section{REMEDIES}

Imagine that a Louisville slaveholder in 1866, upon hearing the news that slavery had been abolished, decided to hold on to Sara, a slave whom he "loved." What cause of action would Sara have had? Shackled, Sara could not have brought suit herself. She would have remained his captive until someone tried to free her. Would the strong words of the Thirteenth Amendment, which state that slavery "shall no longer exist," require the Louisville police to investigate former slaveholders? Would the police have a duty to investigate if the facts were altered and a sympathetic neighbor had told them about Sara's condition? Consider one final situation: Sara stole a loaf of bread, and the police arrested her. While in jail, Sara told the police about her continuing enslavement. Do the police have any obligation to investigate after payment of bail or the end of her sentence? Unless the answer to this last question is yes, the absolute declaration of the Thirteenth Amendment would have been a dead letter in the face of Southern resistance.

\section{A. Recourse Against Pimps and Conspirators-18 U.S.C. \& 1584 and 42 U.S.C. \& 1985(3)}

In any of these situations, the law may offer freedom to both Sara and her modern-day analogue-the forced prostitute. Just as the federal government during Reconstruction could criminally sanction slavemasters, today's federal government may prosecute pimps under 18 U.S.C. $\$ 1584$, which makes it a crime to force someone into slavery. ${ }^{141}$ Under $\S 1584$, the government must prove that the defendant "knowingly and willfully" held someone in "any condition of involuntary servitude." As a criminal remedy with the threat of five years of imprisonment, ${ }^{142}$ this can be a potent weapon in the fight against forced prostitution. If the government knows about her situation and is willing to prosecute her master, she will likely be freed as a practical result of her master's conviction. Criminal sanctions have a further virtue: they do not require the forced prostitute to file papers herself and thus risk retaliation by her pimp. There are drawbacks, however, to relying on $\$ 1584$ alone. First, government officials' biases against prostitutes make these officials unlikely to prosecute pimps. ${ }^{143}$ Second, even if prosecutions occur, criminal sanctions

slavery experts distinguish between forced and unforced prostitution: "[F]orcing the prostitute to adhere to the trade is what makes it slavery. ... The reason for taking a narrower definition here is ... to avoid watering down the concept of slavery. Uncoerced prostitutes, common or rare, are not slaves." ROGER SAWYER, SLAVERY IN THE TWENTIETH CENTURY 101 (1986). Because consensual or voluntary prostitution lacks the element of physical coercion and because the prostitute receives full profits from her work, the Thirteenth Amendment is not implicated.

141. See supra note 100.

142. 18 U.S.C. $\S 1584$ (1988).

143. See supra text accompanying notes 30-37. 
provide no compensation to the prostitute. Moreover, because the burden of proof is high in criminal actions, successful $\S 1584$ prosecutions may be relatively infrequent. Forced prostitutes, like African Americans after the Civil War, need more than declarations of their rights backed up by promises to bring criminal charges against enslavers.

The $42 \mathrm{~d}$ Congress recognized this and passed the Ku Klux Klan Act, which enabled former slaves to sue both private persons and state officials for conspiracies that deprived them of their civil rights. Section 1985(3), the modern version of the Act, is a viable civil alternative for women who want to pursue action against pimps and government officials. ${ }^{144}$ Even if the prostitute is unable to sue (because she is under the pimp's physical control, for instance), a suit may be brought by her next friend. ${ }^{145}$

Section 1985(3) requires proof of three elements. First, the plaintiff must establish that the actions of two or more people constitute a "conspiracy."146

144. Section $1985(3)$ provides in relevant part:

If two or more persons in any State or Territory conspire ... for the purpose of depriving, either directly or indirectly, any person or class of persons of the equal protection of the laws, or of equal privileges and immunities under the laws; or for the purpose of preventing or hindering the constituted authorities of any State or Territory from giving or securing to all persons within such State or Territory the equal protection of the laws ... in any case of conspiracy set forth in this section, if one or more persons engaged therein do, or cause to be done, any act in furtherance of the object of such conspiracy, whereby another is injured in his person or property, or deprived of having and exercising any right or privilege of a citizen of the United States, the party so injured or deprived may have an action for the recovery of damages occasioned by such injury or deprivation, against any one or more of the conspirators. 42 U.S.C. $\$ 1985(3)$ (1988). This statute has five advantages over criminal sanctions. First, it provides for attorney's fees, which creates incentives for both abused women and their attorneys to bring such suits. 42 U.S.C.A. \$ 1988 (West 1981 \& Supp. 1993). Second, $§ 1985(3)$ gives power to the abused woman instead of the state. She controls the case and need not rely on a prosecutor. Third, because $\S 1985(3)$ is a civil action, the standard of proof is lower than that of a criminal proceeding. Fourth, by creating a federal cause of action, prostitutes can try their case before a (perhaps) more sympathetic federal judge. Finally, $\S 1985$ (3) permits a cause of action against government officials. Kenyatta v. Moore, 623 F. Supp. 224, 228 (S.D. Miss. 1985) (stating that $\$ 1985$ (3) includes conspiratorial private action by federal employees); Waller v. Butkovich, 584 F. Supp. 909, 938-39 (M.D.N.C. 1984) (stating that federal officials may be sued under $\$ 1985(3))$.

145. Generally, when a person whose rights have been violated is unable to assert his or her rights, other persons may sue to vindicate that person's rights. Singleton v. Wuiff, 428 U.S. 106, 113-18 (1976) (plurality opinion). Next-friend standing requires an explanation, such as inaccessibility, for why the real party in interest cannot bring the action, as well as proof that the next friend is "truly dedicated to the best interests of the person on whose behalf he seeks to litigate." Whitmore v. Arkansas, 495 U.S. 149, 163 (1990) (promulgating standard in death penalty context).

146. Section 1985(3) does not require elaborate and preplanned conspiracies. See Griffin v. Breckenridge, 403 U.S. 88 (1971) (loose conspiracy of two whites). A plaintiff who meets $\$ 1985(3)$ burdens can also bring suit against any party who had knowledge and was able to prevent the conspiracy:

Every person who, having knowledge that any of the wrongs conspired to be done, and mentioned in section 1985 of this title, are about to be committed, and having power to prevent or aid in preventing the commission of the same, neglects or refuses to do so, if such wrongful act be committed, shall be liable to the party injured . . . .

42 U.S.C. $\$ 1986$ (1988). Government officials who know of a conspiracy but fail to prevent it may be liable under $\S 1986$. Waller v. Butkovich, 584 F. Supp. at 943 (stating that $\S 1986$ requires federal agents with knowledge of Ku Klux Klan rally to take steps to prevent deprivation of rights); Bergman v. United States, 579 F. Supp. 911, 934-35 (W.D. Mich. 1984) (using \$ 1986 to establish negligence per se of United States in failing to prevent violence during freedom ride); Symkowski v. Miller, 294 F. Supp. 1214, 1217 (E.D. Wis. 1969) (finding allegation that police officers witnessed beating and failed to stop it stated valid 
Second, the plaintiff must prove that the conspiracy interfered with rights that were "protected against private, as well as official, encroachment,"147 which is the case with the Thirteenth Amendment. Indeed, the majority, concurrences, and dissents in the Court's recent decision, Bray v. Alexandria Women's Health Clinic, all agree that the Thirteenth Amendment right to freedom from involuntary servitude is undoubtedly protected by $\S 1985(3){ }^{148}$

Finally, a $\S 1985$ (3) plaintiff must prove that "some racial, or perhaps otherwise class-based, invidiously discriminatory animus [lay] behind the conspirators' action." 149 While it seems clear that the class of women is protected under the statute, ${ }^{150}$ the animus requirement might seem to suggest that hostility toward women must be the sole motivation behind the defendant's action. This, however, overreads the Court's pronouncements on this issue. The Court has held that $\S 1985$ (3) demands "at least a purpose that focuses upon women by reason of their sex-for example ... the purpose of 'saving' women because they are women from a combative, aggressive profession such as the practice of law."151 Indeed, the Court has held that a defendant's action, even if not "maliciously motivated," may fall under the statute. ${ }^{152}$ Forced prostitution, which involves enslaving a woman because of her sexual identity, is a deprivation of freedom "by reason of [her] sex."153

cause of action under $\$ 1986$ ). Section 1986 covers private actors as well. Washington v. Duty Free Shoppers, 696 F. Supp. 1323, 1327 (N.D. Cal. 1988) (finding allegation that store managers failed to prevent discrimination stated valid cause of action under $\$ 1986$ ); Vietnamese Fisherman's Ass'n v. Knights of the Ku Klux Klan, 518 F. Supp. 993, 1007 (S.D. Tex. 1981) (holding liable under $\$ 1986$ defendants who knew that $\mathrm{Ku}$ Klux Klan was conspiring to reduce number of Vietnamese fishing boats).

147. Bray v. Alexandria Women's Health Clinic, $113 \mathrm{~S}$. Ct. 753, 758 (1993) (citing Carpenters v. Scott, 463 U.S. 825,833 (1983)).

148. Id. at 764 ("There are few such rights (we have hitherto recognized only the Thirteenth Amendment right to be free from involuntary servitude, and, in the same Thirteenth Amendment context, the right of interstate travel).") (citations omitted); id. at 783 (Stevens, J., dissenting) ("To date, the Court has recognized as rights protected against private encroachment (and, hence, by $\S 1985(3)$ ) only the constitutional right of interstate travel and rights granted by the Thirteenth Amendment."); id. at 774 (Souter, J., concurring in part and dissenting in part) ("If indeed Congress had meant to confine the statute that narrowly, its application to federal constitutional deprivations in 1871 would not have gone beyond violations of the Thirteenth Amendment .....).

149. Griffin, 403 U.S. at 102.

150. Bray, $113 \mathrm{~S}$. Ct. at 759 (declining to reach issue, but noting that statute requires "at least a purpose that focuses upon women by reason of their sex"); $i d$. at 801 (O'Connor, J., dissenting) ("Not surprisingly, the seven federal courts of appeals to have addressed the question have all reached the conclusion that the class of 'women' falls within the protection of the statute.") (citations omitted).

151. Id. at 759. The Court was clearly referring to Justice Bradley's now discredited opinion in Bradwell v. Illinois, 83 U.S. (16 Wall.) 130, 141 (1873) (Bradley, J., concurring in judgment) (upholding exclusion of women from legal profession).

152. Bray, $113 \mathrm{~S}$. Ct. at 759 . Some may argue that pimps are motivated by money rather than by a desire to deprive women of their civil rights and that, therefore, pimps have no discriminatory animus. Regardless of their underlying motives, pimps consciously attempt to deprive their prostitutes of freedom. Their attempts should satisfy $\S 1985(3)$ 's standard of a "purpose of depriving . . . any person . . . of the equal protection of the laws." After all, almost any defendant could plausibly assert that other reasons prompted his or her actions besides discriminatory animus. In fact, most pimps harbor great hatred towards women, see, e.g., MILNER \& MILNER, supra note 12, at 51, which may indeed be leading them to exploit women in particular.

153. Bray, 113 S. Ct. at 759 (emphasis omitted). 


\section{B. Suing the Government and Its Officials-42 U.S.C. $\$ 1983$}

The Louisville slave Sara would be in a precarious position if the government could simply ignore her cries for help. As we have seen, the $\mathrm{Ku}$ Klux Klan Act forbids the government from conspiring to deprive individuals of their civil rights. But what about the times when police simply refuse to act? Congress sought to remedy that situation by creating a cause of action against state inaction. ${ }^{154}$ Section 1983 "specifically encompasses state conduct that either subjects a citizen or 'causes [him] to be subjected' to a deprivation of constitutional rights." 155 This language suggests that successful $\S 1983$ suits may be brought against police officers in both their official and personal capacities, ${ }^{156}$ and against municipalities, ${ }^{157}$ for their failure to prevent slavery. ${ }^{158}$

The clearest case for a suit against the government or its officials occurs when police with knowledge of specific incidents of slavery fail to act. ${ }^{159}$ Without such action, women who have been forced into prostitution will be "subjected to" deprivations of their rights. ${ }^{160}$ The Thirteenth Amendment

154. This Note limits its discussion of remedies to those that can be sought in court from municipal officials and police. It does not consider actions for damages against state officials in their official capacities, because any such action-at least if brought in federal court-would be barred by the doctrine of state sovereign immunity under the Eleventh Amendment. See Hans v. Louisiana, 134 U.S. 1 (1890). A plaintiff could sue states or state officials for equitable relief in federal court; the Eleventh Amendment as interpreted in Hans does not bar federal courts from granting such relief. Ex parte Young, 209 U.S. 123 (1908). A plaintiff might also be able to sue federal officials for money damages directly under the Thirteenth Amendment, see Bivens v. Six Unknown Named Agents of Fed. Bureau of Narcotics, 403 U.S. 388 (1971); or for equitable relief, since the federal government has waived sovereign immunity in actions seeking "relief other than money damages," 5 U.S.C. $\$ 702$ (1988).

155. Amar \& Widawsky, supra note 7, at 1382 n.97 (quoting 42 U.S.C. $\$ 1983$ (1988)). Section 1983 creates a cause of action for damages against "[e]very person who, under color of any statute, ordinance, regulation, custom, or usage . . . subjects, or causes to be subjected, any citizen of the United States or other person within the jurisdiction thereof to the deprivation of any rights, privileges, or immunities secured by the Constitution and laws ... " 42 U.S.C. $\$ 1983$ (1988). In addition to the benefits inherent to civil actions, see supra note $144, \S 1983$ suits are attractive because the woman may be afraid to sue her pimp.

156. Personal liability under $\$ 1983$ requires a plaintiff to show that "the official, acting under color of state law, caused the deprivation of a federal right." Kentucky v. Graham, 473 U.S. 159, 166 (1985). Official liability requires proof that the governmental entity was a "moving force" behind the violation. Id. One major drawback of official liability is that punitive damages are not available whereas in personal liability actions they are. $I d$. at 167 n.13.

157. Monell v. Department of Social Servs., 436 U.S. 658 (1978).

158. Under the Supreme Court's most recent formulation of $\$ 1983$, a plaintiff "must allege that some person has deprived him of a federal right," and "must allege that the person who has deprived him of that right acted under color of state or territorial law." Gomez v. Toledo, 446 U.S. 635, 640 (1980). Though the Supreme Court did not discuss the phrase "causes him to be subjected," that language should be given effect, since the Thirteenth Amendment was passed contemporaneously with the Act. Other courts phrase the requirements without mentioning the need for direct state action. See, e.g., Zamlen v. City of Cleveland, 906 F.2d 209, 214 (6th Cir. 1990) ("[P]laintiffs must demonstrate (1) a deprivation of rights protected under the federal constitution and (2) action under color of state law.") (citations omitted).

159. Police sometimes know about specific locations where children are kept in "fortresses" for prostitution. CAMPAGNA \& POFFENBERGER, supra note 26, at 110.

160. The causation requirement should be read in light of the history of the Civil Rights Act, which penalized inaction of marshals, district attorneys, and others who had knowledge of impending conspiracies. 
means that if government officials have specific knowledge that a woman is enslaved, they are under a duty to investigate. Police are sometimes privy to such information from prostitutes since police arrest and detain them. Regardless of whether the police obtain their knowledge from informers, johns, or others, if they have evidence that creates a suspicion of slavery, they must investigate. In other contexts, courts have found that officers with specific knowledge of actual-and sometimes potential-crimes are under a duty to investigate and act under $\S 1983 .{ }^{161}$ Other courts have found that when the law imposes duties on government officers, they may be held liable for their omissions under $\S 1983 .^{162}$

Once instances of forced prostitution are discovered, governments may not be under an obligation to criminally charge slave masters, nor must they necessarily seek criminal fines, but at the very least, governments must liberate women from captivity. At a minimum, therefore, prostitutes who notify the police during their enslavement will have $\S 1983$ causes of action against the police officers if they fail to investigate. In addition, plaintiffs may be able to argue that municipalities and local officials are liable for their failure to train officers to recognize instances of slavery. ${ }^{163}$ Liability may also be established

\footnotetext{
See supra note 146; infra note 175.

161. See, e.g., Thurman v. City of Torrington, 595 F. Supp. I521, 1527 (D. Conn. 1984) ("If officials have notice of the possibility of attacks on women in domestic relationships or other persons, they are under an affirmative duty to take reasonable measures to protect the personal safety of such persons in the community. Failure to perform this duty would constitute a denial of equal protection of the laws."); Bartalone v. County of Berrien, 643 F. Supp. 574, 577 (W.D. Mich. 1986) (holding that Equal Protection Clause forbids police officer from failing to prevent husband from battering wife); Smith v. Ross, 482 F.2d 33, 37 (6th Cir. 1973) (noting that police failure to protect black citizens from $\$ 1985$ conspiracy could be actionable under $\S 1983$ as violation of equal protection); Saviour v. City of Kansas City, No. 90-2430-L, 1992 U.S. Dist. LEXIS 8813, at *23 (D. Kan. May 15, 1992) ("IA]n officer who is present at the scene and who fails to take reasonable steps to protect the victim of another officer's use of excessive force, can be held liable for his nonfeasance.") (citation omitted); Dudosh v. City of Allentown, 629 F. Supp. 849, 855 (E.D. Pa. 1985) (holding that restraining orders and phone calls to the police from murder victim may create special relationship for due process purposes under $\$ 1983$ ); Cooper v. Molko, 512 F. Supp. 563, 567 (N.D. Cal. 1981) (noting that failure of police to rescue abducted youth is actionable under $\$ 1983$ because it "is clear that $\$ 1983$ was intended to apply to acts by police officers of omission as well as commission").

162. Mody v. City of Hoboken, 758 F. Supp. 1027, 1032 (D.N.J. 1991) (holding that failure to file charges against individuals who assaulted Indian Americans states cause of action under $\$ 1983$ and equal protection clause); Waller v. Butkovich, 584 F. Supp. 909, 942 (M.D.N.C. 1984) (noting that First Amendment requires police to protect dissenters and picketers from violence).

163. In the context of other constitutional rights, a plaintiff must prove that the municipality's "policy or custom" was the cause of her injury and that the failure to train amounts to "deliberate indifference" to the rights of persons with whom the police come into contact. City of Canton v. Harris, 489 U.S. 378, 38889 (1989) (remanding failure to train suit where plaintiff alleged suffering from lack of medical care while in police custody). A municipality acts with "deliberate indifference" when the "need for more or different training is so obvious, and the inadequacy so likely to result in the violation of constitutional rights." Id. at 390 . The Court stated that

city policymakers know to a moral certainty that their police officers will be required to arrest fleeing felons. The city has armed its officers .... Thus, the need to train officers in the constitutional limitations on the use of deadly force . . . can be said to be 'so obvious,' that failure to do so could properly be characterized as 'deliberate indifference' to constitutional rights.
} 
against the municipality if plaintiffs could show that the official custom of the police department showed "deliberate indifference" to forced prostitution. ${ }^{164}$ Akhil Amar and Daniel Widawsky have recently argued that "once any arm of the state knows of present, identifiable slavery within its territory, the state must take reasonable steps to end the enslavement." 165 This is true because "the Amendment requires state action . . . . Under the principles of Bivens and 42 U.S.C. $\$ 1983$, state officials can and should be held liable for the violation of their constitutional duties." 166 While they tied their view of state action to incidents where the state already had knowledge of slavery, Thirteenth Amendment remedies may also cover situations where government officials have constructive knowledge. ${ }^{167}$

Just as the government passed the Freedmen's Bureau Act and the Civil Rights Act out of a belief that African-Americans were in danger of reenslavement, ${ }^{168}$ governments today should be presumed to have constructive

Id. at 390 n.10 (citation omitted); see also Davis v. Mason County, 927 F.2d 1473 (9th Cir. 1991) (upholding municipal liability for sheriff's training practices regarding excessive force); Meade v. Grubbs, 841 F.2d 1512, 1530 (10th Cir. 1988) (reinstating $\$ 1983$ claim that sheriff is liable in his official capacity because of poor training and supervision of prison officials). Liability for failure to train is itself a remedy against state inaction; a municipality may be liable "due to the existence of an improper policy or from the absence of a policy." Rivas v. Freeman, 940 F.2d 1491, 1495 (11th Cir. 1991); Waller, 584 F. Supp. at 945 (official's inaction regarding supervision may violate $\$ 1983$ ).

164. Policies need not be written down to establish municipal liability. Monell v. Department of Social Servs., 436 U.S. 658, 690-91 (1978). One possible way to establish police custom is through the use of statistics. See, e.g., Watson v. City of Kansas City, 857 F.2d 690, 695 (10th Cir. 1988) (finding statistics that document a higher arrest rate for nondomestic than domestic assaults relevant to establishing official custom). If the plaintiff can prove that officials were aware of patterns of abuse and failed to take action, the officials may be liable under $\S 1983$. Walker v. City of New York, 974 F.2d 293, 300 (2d Cir. 1992) (officials who are aware of pattern of perjury among police officers may be found liable for failure to train and supervise); Sango v. City of New York, No. 83-CV-5177, 1989 U.S. Dist. LEXIS 18214, at *19, *27 (E.D.N.Y. June 16, 1989) (municipal supervisors' inaction in response to claims of police misconduct may establish municipal liability). Plaintiffs in other contexts have been able to infer training and supervisory practices from the internal disciplinary practices of the police. See Estate of Sinthasomphone v. City of Milwaukee, 785 F. Supp. 1343, 1350-51 (E.D. Wis. 1992) (finding that disciplinary action of police department may be used to infer municipal custom under Monell rule); Wilson v. City of Chicago, 707 F. Supp. 379, 381-82 (N.D. Ill. 1989) (similar holding). Because so much of this data is in the hands of government officials, plaintiffs should have the benefit of liberal pleading rules and broad discovery powers.

165. Amar \& Widawsky, supra note 7, at 1381 (emphasis omitted); see also Doe v. Johnson, No. $92-$ C-7661, 1993 U.S. Dist. LEXIS 3284, at *8 (N.D. Ill. Mar. 11, 1993) (suggesting that in child abuse case Fourteenth Amendment contains state action trigger while Thirteenth Amendment does not); Koppelman, supra note 98, at 533 (defending affirmative duty in abortion context); JACOBUS TENBROEK, EQUAL UNDER LAW 157-73 (1965).

166. Amar \& Widawsky, supra note 7, at 1381-82. The discretionary language of $\$ 2$ of the Thirteenth Amendment does not mean that $\$ 1$ loses its mandatory force. It would indeed be a curious result if $\S 2$, which merely clarifies Congress's power over slavery, restricted the force of $\$ 1$. "The second clause of that amendment was inserted ... for the purpose, and none other, of preventing State Legislatures from enslaving, under any pretense, those whom the first clause declared should be free." CONG. GLOBE, 39th Cong., Ist Sess. 43 (1865) (statement of Sen. Trumbull).

167. States that take Amar and Widawsky's argument seriously might have a clear ex ante incentive to look the other way so that such knowledge could never be used against them. However, the conscious choice to refrain from collecting information is itself state action. Since Amar and Widawsky's own conception allows broader remedies when state action is present, Amar \& Widawsky, supra note 7, at 1382 $\mathrm{n.98}$, their argument sets up a cause of action when states act with willful blindness.

168. See infra notes 173-74. 
knowledge that slavery exists in America's cities. For instance, when prostitutes are arrested, pimps often post bail for them. ${ }^{169}$ By posting bail, pimps create implicit service contracts; a pimp may threaten to inform the police of the prostitute's illegal activities unless she agrees to work for him. Because this bail arrangement is so common, courts should consider the police to have constructive knowledge of the likelihood of force. At a minimum, the police should ask prostitutes if they have been forced into prostitution. Since police know the names of the women they arrest and the names of those who bail them out, they can easily monitor situations of suspected force.

Some readers may feel that this reading of $\S 1983$ makes all rights of the Constitution affirmative guarantees. My interpretation of this statute in the Thirteenth Amendment context, however, extends no further than courts have regularly applied $\S 1983$ when protecting other constitutional rights. ${ }^{170}$ Moreover, presuming constructive knowledge in slavery cases may make even more sense than presuming it in these other contexts for two reasons. First, congressional debates over the Civil Rights Act of 1866 (the precursor to $\S 1983$ ) were inextricably tied to the Thirteenth Amendment. ${ }^{171}$ A principal supporter of the Act states: "Now, there are two ways in which a State may undertake to deprive citizens of these absolute, inherent, and inalienable rights: either by prohibitory laws, or by a failure to protect any one of them."172 The language in the Act may have derived from the oft-repeated "duty" to abolish slavery. ${ }^{173}$ In the years after the Civil War, the federal government

169. Baldwin Brief, supra note 22, at $127 ; J$, in THE Prostitution PAPERs 74 (Kate Millett ed., Avon Books 1973) (1971).

170. See cases cited supra notes 161 and 163 .

171. Indeed, both $\$ 1983$ and the 1866 Act contain the same phrase, "causes to be subjected." 42 U.S.C. \$ 1983 (1988); Civil Rights Act of 1866, ch. 31, 14 Stat. 27 (1866). Congress may have passed the 1866 Act as a result of its belief that the Thirteenth Amendment compelled the practical elimination of slavery. See CONG. GlOBE, 39th Cong., 1st Sess. 684 (1866) (statement of Sen. Sumner) ("Beyond all question the protection of colored persons in civil rights is essential to complete the abolition of slavery .... [There is an] obligation of Congress to 'enforce' the abolition of slavery."); CONG. GLOBE, 39th Cong., 1st Sess. 503-04 (1866) (statement of Sen. Howard) (arguing that Amendment's framers foresaw the need for Civil Rights Bill). The author of the Act, Senator Trumbull, emphasized that the Amendment created a "duty" upon Congress to protect the civil rights of freed slaves. CONG. GLOBE, 39th Cong., 1st Sess. 322 (1866).

172. CONG. GLOBE, 39th Cong., 1st Sess. 1833 (1866) (statement of Rep. Lawrence) (emphasis added). Other members of Congress argued that the Amendment was a promise to ensure the freedom of former slaves. See, e.g., CoNG. GLoBE, 39th Cong., 1st Sess. 298 (1866) (statement of Sen. Stewart).

173. Senator Trumbull noted that "under the constitutional amendment Congress is bound to see that freedom is in fact secured to every person throughout the land; he must be fully protected in all his rights of person and of property," and that "any legislation or any public sentiment which deprives any human being in the land of those great rights of liberty will be in defiance of the Constitution, and if the States and local authorities, by legislation or otherwise, deny these rights, it is incumbent on us to see that they are secured." CONG. GLOBE, 39th Cong., 1st Sess. 77 (1865). For similar statements by Sen. Trumbull's, see CONG. GLOBE, 39th Cong., 1st Sess. 43 (1865) (without rights guaranteed by the Thirteenth Amendment, former slaves "would not be freemen"; "It is idle to say that a man is free who cannot go and come at pleasure, who cannot buy and sell, who cannot enforce his rights. These are rights which the first clause of the constitutional amendment meant to secure to all . ..."); CONG. GLOBE, 39th Cong., 1st Sess. 323 (1866). Trumbull was a guiding force in drafting the Thirteenth Amendment, the Civil Rights Act of 1866, and the 1866 Freedmen's Bureau Bill. GEORGE R. BENTLEY, A HISTORY OF THE FREEDMEN'S 
repeatedly intervened in the domestic affairs of Southern states to ensure that slavery would not continue. ${ }^{174}$ And in a host of measures enacted after the Civil War, Congress forced officials to investigate and eliminate instances of slavery. ${ }^{175}$ Second, court decisions cast the Thirteenth Amendment in a much

BUREAU 115 (Octagon Books 1970) (1944). Trumbull's argument was repeated five years later by Sen. Edmunds:

If, as under the thirteenth article, slavery was a constitutional institution . . . a great change has come over the spirit of this Government; and instead of its being a Government of slavery, tolerated or upheld or winked at, it has become a Government of freedom; that instead of its being a Government which should suffer the local authorities of a State to deny the common rights of citizens to any of its people, it has become a Government in which the national power has guaranteed it to them, and which it is the duty of the national power ... in the most exhaustive sense, to see is fully and fairly enforced and made a practical reality.

CONG. GLOBE, 42d Cong., 1st Sess. 697 (1871) (emphasis added).

174. The Freedman's Bureau was created in 1863, and was given additional power in 1866, despite President Andrew Johnson's veto of the 1866 bill. In one of his most important speeches, Trumbull attacked Johnson's veto by using an affirmative vision of the Thirteenth Amendment:

If legislation be necessary to protect the former slaves against State laws . . . has not Congress, under the second clause of the amendment, authority to provide it? What kind of freedom is that which the Constitution of the United States guaranties [sic] to a man that does not protect him from the lash if he is caught away from home without a pass? And how can we sit here and discharge the constitutional obligation that is upon us to pass the appropriate legislation to protect every man in the land in his freedom when we know such laws are being passed in the South if we do nothing to prevent their enforcement? Sir, so far from the bill being unconstitutional, I should feel that I had failed in my constitutional duty if I did not propose some measure that would protect these people in their freedom.

CONG. GLOBE, 39th Cong., Ist Sess. $941-42$ (1866). Other members of Congress voiced similar arguments. CoNG. GlobE, 39th Cong., 1st Sess. 656 (1866) (statement of Rep. Eliot) ("But the power to free them involved the duty to protect them, and for that protection Congress must provide ..... And the second section of [the Thirteenth] amendment confers the power and so creates the duty for just such legislation as this bill contains . . . "); CONG. GlOBE, 39th Cong., 1st Sess. 110 (1866) (statement of Sen. Stewart). The Freedmen's Bureau sought to prevent violence against blacks. See generally CONG. GLOBE, 39th Cong., 1st Sess. 339-40 (1866) (statement of Sen. Wilson); CoNG. GLOBE, 39th Cong., Ist Sess. 78 (1866) (statement of Gen. Ulysses S. Grant); LindA W. SLAUGHTER, THE FreEdMen OF THE SOUTH 92 (Kraus Reprint Co. 1969) (1869). Some of this violence was the result of former masters attempting to prevent former slaves from leaving their plantations. ERIC FONER, RECONSTRUCTION 121 (1988). Indeed, "virtually all [Freedmen's Bureau] agents insisted that planters acknowledge that their power to employ physical coercion had come to an end," id. at 165 , and the Bureau's very presence undermined the vestiges of slavery. Id. at 168. For that reason, the newly freed slaves saw the Bureau as a major protector against the violence and coercion of former masters. Id. at 169 . In addition to the Bureau, the federal government dispatched troops and federal marshals to safeguard the rights of African Americans under the Civil Rights Acts. Lerone BennetT, JR., Black POWER U.S.A.: The Human Side of ReCONSTRuction, 1867-1877, at 347 (1967).

175. The Civil Rights Act of 1866 imposed several affirmative duties on government. First, $\S 2$ of the Act created a cause of action against anyone who, under color of state law, "shall subject, or cause to be subjected, any inhabitant . . . to the deprivation of any right secured or protected by this act." Civil Rights Act of 1866, ch. 31, 14 Stat. 27 (1866). The "color of law" requirement may have its roots in the 1863 Habeas Corpus Act, which covered actions against officers and other persons for their "wrongs done ... or any act omitted to be done." Ch. 81, 12 Stat. 756 (1863). Section 2 of the Civil Rights Act of 1866 eventually became 42 U.S.C. $\$ 1983$ (1988). Second, under $\$ 4$ of the 1866 Act, district attomeys, U.S. marshals, and the officers and agents of the Freedmen's Bureau were "authorized and required, at the expense of the United States, to institute proceedings against all and every person who shall violate the provisions of this act." Civil Rights Act of 1866, ch. 31, 14 Stat. 28 (1866). The source of the "authorized and required" language may be a 1790 Act which "authorized and required" U.S. marshals to take the new nation's first census. 1 Stat. 101 (1789). This parallel language is significant because the U.S. government has an affirmative duty under the Constitution to undertake a decennial census. Section 4 of the Civil Rights Act is now 42 U.S.C. $\S 1987$ (1988). Third, $\S 5$ of the 1866 Act made it a criminal offense for a marshal to disregard a warrant issued under the Act. Civil Rights Act of 1866, ch. 31, 14 Stat. 28 (1866). 
more affirmative tone than other rights. The words of one of the earliest Thirteenth Amendment cases are worth recalling: "[T]he Amendment is not a mere prohibition of State laws establishing or upholding slavery, but an absolute declaration that slavery or involuntary servitude shall not exist in any part of the United States." ${ }^{176}$ Since the Thirteenth Amendment is the only Amendment which has been interpreted to have no state action trigger, it is the only Amendment where private actors could deprive a person of her "constitutional rights." 177

Even under this reading of $\S 1983$, government officials possess a range of legal defenses. Actions against officers in their personal capacity will immediately face the hurdle of qualified immunity. ${ }^{178}$ The doctrine of qualified immunity states that "government officials performing discretionary functions, generally are shielded from liability for civil damages insofar as their conduct does not violate clearly established statutory or constitutional rights of which a reasonable person would have known."179 At worst, this means that a plaintiff, in the very first suit to establish a violation of $\S 1983$ by government officials in a Thirteenth Amendment case, may be able to gain

One court explained the necessity of criminalizing such government inaction: "The United States marshals being presidential appointees, and the hostility of Mr. Johnson to the civil rights bill being notorious, it was apprehended that the marshals would not enforce the law. Hence the . . . provision making it highly penal in such officers to refuse or fail to execute writs . . . " In re Upchurch, 38 F. 25, 27 (C.C.E.D.N.C. I889).

176. Civil Rights Cases, 109 U.S. 3, 20 (1883). The positive nature of the Amendment is reflected in language from other cases. Justice Harlan argued that it "operated not only to annul state laws upholding that institution, but to establish 'universal civil and political freedom throughout the United States,' and to invest every individual person within their jurisdiction with the right of freedom . . . ." Baldwin v. Franks, 120 U.S. 678, 698 (1887) (Harlan, J., dissenting) (quoting Civil Rights Cases, 109 U.S. at 20). Similarly, Justice Bradley called the Amendment "a positive declaration that slavery shall not exist," and noted that the "amendment had an affirmative operation the moment it was adopted." United States v. Cruikshank, 25 F. Cas. 707, 711 (C.C.D. La. 1874) (No. 14,897). And Justice Chase likewise argued that the Amendment "establishes freedom as the constitutional right of all persons in the United States." In re Turner, 24 F. Cas. 337, 339 (C.C.D. Md. 1867) (No. 14,247). Cases brought under the antipeonage statute, now codified at 42 U.S.C. $\$ 1994$, also hint at the Amendment's affirmative nature. See Pollock v. Williams, 322 U.S. 4, 17 (1944) ("The undoubted aim of the Thirteenth Amendment as implemented by the Antipeonage Act was not merely to end slavery but to maintain a system of completely free and voluntary labor throughout the United States."); In re Lewis, 114 F. 963, 966 (C.C.N.D. Fla. 1902).

177. To put the point a different way, if the police locked up Jesse Helms for speechifying, that would violate the First Amendment. If demonstrators shouted him down at a political rally, however, it would not.

178. Suits against officials in their public capacity are not protected by qualified official immunity. Rivas v. Freeman, 940 F.2d 1491, 1494-95 (11th Cir. 1991). Likewise, qualified immunity offers no protection for suits against municipalities. Owen v. City of Independence, 445 U.S. 622, 650-57 (1980).

179. Harlow v. Fitzgerald, 457 U.S. 800, 818 (1982). While this language is quite restrictive, the Court later said that "[t]his is not to say that an official action is protected by qualified immunity unless the very action in question has previously been held unlawful . . but it is to say that in light of pre-existing law the unlawfulness must be apparent." Anderson v. Creighton, 483 U.S. 635, 640 (1987) (citations omitted). To put this another way: "There has never been a section 1983 case accusing welfare officials of selling foster children into slavery; it does not follow that if such a case arose, the officials would be immune from damages liability ...." K.H. ex rel. Murphy v. Morgan, 914 F.2d 846, 851 (7th Cir. 1990). An official's failure to act is not protected by qualified immunity if a "reasonable" official would have understood that such inaction violated a plaintiff's constitutional rights. Moffitt v. Town of Brookfield, 950 F.2d 880, 88586 (2d Cir. 1991) (explaining this standard in the context of due process). 
only an equitable or declaratory ${ }^{180}$ judgment against the individual police officers. After that case, however, suits for failure to prevent slavery will not fail for lack of a "clearly established constitutional right." Qualified immunity exists only to shield an officer from liability in cases where the law is murky; it does not bar interpolation of legal principles that already exist. ${ }^{181}$

Many women, however, are unlikely to tell government officials that they have been forced into prostitution. Since today's prostitutes have been abused, arrested, and forgotten by the police, it is no wonder that they do not trust state officials. ${ }^{182}$ However, a strong set of $\S 1983$ remedies against the police, coupled with increased use of $\S 1584$, may produce incentives for more women to come forward. In addition, legislatures and municipalities must take steps to encourage cooperation between officials and prostitutes. Indeed, even if courts are reluctant to impose liability in particular cases, governments should realize that they are constitutionally obligated to abolish slavery, and should redirect their resources accordingly.

These legislative steps require restructuring the way governments deal with prostitution. Currently, prostitutes do not trust police-with good reason, since police frequently inflict physical brutalities on prostitutes. Police may need to work with prostitutes, instead of against them, to facilitate arrests of procurers. ${ }^{183}$ Even if police arrest a known pimp, the testimony of prostitutes is essential to a conviction. It remains to be seen whether the need for

180. Plaintiffs may also be able to obtain injunctions against state practices that subject them to abuse. Cases brought on other grounds, such as due process, may serve as a model here. See, e.g., L.J. v. Massinga, 838 F.2d 118, 120-22 (4th Cir. 1988) (due process clause requires state and local officials to increase monitoring, treatment, planning, and supervision of all children placed in foster homes).

181. Qualified immunity involves balancing the individual rights at issue against the harm such liability would impose on the governmental entity. Valdez v. Denver, 878 F.2d 1285, 1287 (10th Cir. 1989) (explaining balancing test); In re Perry, 882 F.2d 534, 544 (1st Cir. 1989) ("In sum, there is a fundamental distinction at work. Civil rights statutes like 42 U.S.C. $\$ \S 1983,1988$ are to be construed generously to effectuate their salutary purposes ... and the course of such construction may require . . . that personal immunities be submerged.") (citations omitted). It is difficult to come up with a right more fundamental than the right to be free from slavery. Indeed, early discussions of the Civil Rights Acts failed to mention immunity. See, e.g., Tuchman v. Welch, 42 F. 548, 558 (C.C.D. Kan. 1890) ("[Civil Rights Act] is as comprehensive as it is explicit. It applies to any person, no matter who, officer or layman ....."); CoNG. GLOBE, 39th Cong., 1st Sess. 500 (1866) (Sen. Cowan asked, "Is there not a provision by which State officers are to be punished?" and Trumbull replied, "Not State officers especially, but everybody who violates the law. It is the intention to punish everybody who violates the law."). Moreover, widespread indemnification of police officers, see, e.g., Theodore Eisenberg \& Stewart Schwab, The Reality of Constitutional Tort Litigation, 72 CORNELL L. REV. 641, 686 \& n.186 (1987), significantly undercuts the policy reasons for immunity in the first place. For additional discussion of indemnity, see Judge Posner's provocative opinion in Morgan, 914 F.2d at 850.

182. See supra notes $34-35$ and accompanying text.

183. "[T]he pimp squad's avowed aim is to prosecute bad pimps .... [T]he only way to do this effectively is to create an atmosphere of trust between themselves and the prostitutes." SERENY, supra note 26, at 5. One observer has suggested "innovative investigation and arrest procedures for pimps," namely: (1) encouraging police in radio cars to cover areas besides those where streetwalkers are concentrated; (2) assigning more female officers to areas of prostitution; and (3) training vice officers to cover entire networks instead of specific geographic areas. BERNARD COHEN, DEVIANT STREET NETWORKS 157 (1980). Because there are many more prostitutes than pimps, shifting resources to attack pimps may also be a more efficient way to reduce prostitution. Id. 
cooperation between police and prostitutes requires prostitution to be fully decriminalized. ${ }^{184}$ If governments could take less drastic measures that would structure the system to encourage such trust, then perhaps decriminalization would not be needed to facilitate cooperation. One simple partial solution to this problem may be to hire more women police officers. ${ }^{185}$ In 1989 , only eight percent of police officers were women. ${ }^{186}$ In addition, all police officers should be taught to spot instances of forced prostitution and should be trained to be more sensitive to the issues involved.

Another possible solution would be to provide shelters, outreach services, and a relocation system, similar to a government-operated underground railroad, for prostitutes who escape from their pimps. These agencies should be primarily concerned with facilitating the woman's escape, not her arrest. This approach was tried in Sweden with success. ${ }^{187}$ Creating an underground railroad is a critical step in bridging the gap between prostitutes and police and will encourage more prostitutes to testify against their masters. ${ }^{138}$ Some police departments have "provid[ed] emotional and residential support services to prostitutes, as well as provid[ed] protection from the pimp. Police officers in Seattle and Minneapolis ... suggest that when the police take time to be supportive to female prostitutes, they are more willing to testify."189

Opponents may argue that these legislative proposals and expanded prosecutorial and investigatory duties place an intolerable burden on government officials. But would these opponents voice the same argument if the government knew that an African-American man was working in chains in the cotton fields of South Carolina? There were millions of slaves in 1866, but that didn't allow the government to stand by idly while Southern masters

184. Decriminalization supporters argue that the government should permit prostitution as long as a woman can "freely leave prostitution at any time she chooses." Barry, supra note 4 , at 25 . Their proposals would eliminate prohibitions and regulations on prostitution and replace them with laws against procuring. It is no coincidence that this approach has been called "abolitionism." Fernand-Laurent, supra note 3, at 17; see also BARRY, supra note 10, at 234 . Decriminalization may remove some of the stigma that prevents the criminal justice system from listening to prostitutes. JAMES ET AL., supra note 138, at 55 . One prostitute compared state licensing of prostitution, in contrast to decriminalization, to slavery: "Lately, apologists . . . [have] hailed this enslavement of women as 'sexual freedom' .... Decriminalization would in no way increase the incidence or availability of female prostitution, but it would frustrate the exploitation of prostitutes by the two classes of men who are their chief predators: pimps and police." $K$, in THE PROSTITUTION PAPERS, supra note 169, at 81, 82-84 (emphasis added).

185. Fernand-Laurent, supra note 3, at 20.

186. Federal Bureau of INVESTIGATION, U.S. DeP'T OF Justice, UNIFORM CRIME REPorTS 1989: CRIME IN THE UNITED STATES 241 (1990).

187. Swedish municipalities created support groups and social services for prostitutes. "The campaign has been largely successful . . . [and] pimping rings have lost their position in the prostitution economy. ... [I]t offers some evidence that feminists can use political power to raise consciousness about prostitution issues, guide the discourse, and influence the public policy adopted." HOBSON, supra note 95, at 162.

188. CAMPAGNA \& POFFENBERGER, supra note 26, at 113; BARLAY, supra note 17 , at 259 ("[Prostitutes] could and would call for help or advice if they knew where to go for it; and if they knew they could trust such a specialized organization-particularly if they were reassured that this organization was not bound to initiate legal preceedings [sic] that might cause embarrassment or danger to the slaves and informers.").

189. WeISBERG, supra note 11 , at 231. 
adamantly kept their slaves in chains. Likewise, the government today must devote its resources to fighting prostitution, or face potential Thirteenth Amendment lawsuits. ${ }^{190}$

Opponents essentially fear that it costs too much to enforce the law. Cost, however, would not necessarily increase under a regime that complies with the Thirteenth Amendment. Instead of spending hundreds of millions of dollars arresting prostitutes, ${ }^{191}$ we should devote our precious resources to fighting pimps. In 1870 we did not punish the slave, we punished the slave master. More to the point: arguments about cost have no place in the Thirteenth Amendment context. The Thirteenth Amendment does not say, "Slavery shall not exist except where cost-benefit analysis suggests that the government should not eradicate it." It says, "Neither slavery nor involuntary servitude . . . shall exist . . ." ${ }^{192}$ This is an absolute prohibition against slavery; arguments about cost are as irrelevant here as they are in determining whether the Constitution requires congressional elections. The Thirteenth Amendment prohibits the government from standing by idly while women are forced into slavery.

\section{CONCLUSION}

The Thirteenth Amendment has been described "as a full response to the evil perceived. As modern perceptions of that evil grow, the response may take on increasingly broader scope."193 Perhaps because of this, it has enjoyed a revival in the past few years. ${ }^{194}$ And not without cause. The Amendment was enacted to prevent people from being treated as property-precisely what

190. Personal defendants may argue that they are absolutely immune from civil damage actions because budgetary constraints prevent them from prosecuting this type of crime. See Youngberg v. Romeo, 457 U.S. 307, 323 (1982) (establishing possibility of such a defense in due process context). Defendants who assert this defense will face an uphill battle. See McCord v. Maggio, 927 F.2d 844 (5th Cir. 1991) (noting that the defense "carries a highly difficult burden" and that it will not be permitted if "any feasible alternative" to the deprivation existed); Birrell v. Brown, 867 F.2d 956, 959 (6th Cir. 1989) (affirming Youngberg budgetary immunity, but noting that this does not "excuse the constitutional violations themselves, or prevent court orders that require the government to correct deficiencies") (citation omitted); Scott ex rel. Weintraub v. Plante, 691 F.2d 634, 637 (3d Cir. 1982) (stating that Youngberg budgetary defense requires proof that injuries were "causally related" to budgetary problems). Moreover, the fact that police receive millions of dollars to combat prostitution, infra note 191, undermines any budgetary constraints defense. Police could just as easily (and perhaps more successfully) fight the most degrading instances of prostitution by redirecting some of their resources towards fighting procurers. Finally, Youngberg's immunity defense may permit a personal-capacity suit against the officials responsible for the budgetary constraints. K.H. ex rel. Murphy v. Morgan, 914 F.2d 846, 854 (7th Cir. 1990) ("The officials responsible for the inadequacy of those resources might be liable in damages.").

191. Julie Pearl, Note, The Highest Paying Customers: America's Cities and the Costs of Prostitution Control, 38 HASTINGS L.J. 769, 769-80 (1987). Sixteen cities spent more than $\$ 120$ million artesting prostitutes in one year. Id. at 780 .

192. U.S. CONST. amend. XIII, $\$ 1$.

193. Note, The "New" Thirteenth Amendment: A Preliminary Analysis, 82 HARV. L. REV. 1294, 1302 (1969).

194. See supra note 98. 
pimps do to countless women today. Deprivation of freedom and the right to benefit from one's own labor is not something we can or should ignore. All of the essential elements of antebellum slavery are present in the pimpprostitute relationship, whether they be power, physical abuse, or lack of free will; pimps have recreated a modern-day form of slavery. If forced prostitutes today are not slaves, then neither was half of the Southern black population in 1850. 